\title{
Effect of exopolysaccharide produced by isogenic strains of Lactococcus lactis on half-fat Cheddar cheese
}

\author{
N. E. Costa, ${ }^{*}$ J. A. Hannon, ${ }^{* 1}$ T. P. Guinee, ${ }^{*}$ M. A. E. Auty, ${ }^{*}$ P. L. H. McSweeney, $†$ and T. P. Beresford* \\ ${ }^{*}$ Moorepark Food Research Centre, Teagasc, Fermoy, County Cork, Ireland \\ †School of Food and Nutritional Sciences, University College Cork, Cork, Ireland
}

\begin{abstract}
Fat-reduced cheeses often suffer from undesirable texture, flavor, and cooking properties. Exopolysaccharides (EPS) produced by starter strains have been proposed as a mechanism to increase yield and to improve the texture and cooking properties of reduced-fat cheeses. The objective of this work was to assess the influence of an exopolysaccharide on the yield, texture, cooking properties, and quality of half-fat Cheddar cheese. Two pilot-scale half-fat Cheddar cheeses were manufactured using single starters of an isogenic strain of Lactococcus lactis ssp. cremoris (DPC6532 and DPC6533) that differed in their ability to produce exopolysaccharide. Consequently, any differences detected between the cheeses were attributed to the presence of the exopolysaccharide. The results indicated that cheeses made with the exopolysaccharide-producing starter had an $8.17 \%$ increase in actual cheese yield (per $100 \mathrm{~kg}$ of milk), a $9.49 \%$ increase in moisture content, increase in water activity and water desorption rate at relative humidities $\leq 90 \%$, significant differences in the cheeses microstructure, and a significant improvement in both textural and cooking properties, without negatively affecting the flavor profiles of the cheeses.
\end{abstract}

Key words: exopolysaccharide, Cheddar cheese, lowfat, yield

\section{INTRODUCTION}

The health-conscious consumer prefers a diet that is low in fat, and considerable effort has been expended in the development of reduced-fat cheeses. However, reduced-fat cheeses suffer from undesirable characteristics in terms of their texture, flavor, and cooking properties (Mistry, 2001). By reducing the fat content, the microstructure of low-fat Cheddar cheese has a more compact protein network with fewer open spaces, which has a major effect on the functionality and flavor (Bry-

Received December 19, 2009

Accepted April 18, 2010.

${ }^{1}$ Corresponding author: john.hannon@teagasc.ie ant et al., 1995). An effective approach to increasing the quality of reduced-fat cheese is to reduce the density of the casein matrix by increasing the moisture:protein ratio (Guinee and McSweeney, 2006). To increase the moisture level several variations of the cheesemaking procedure have been proposed, such as cutting the rennet curd at a higher firmness, lower cooking temperatures, higher $\mathrm{pH}$ at draining and milling, inclusion of whey proteins, and milk homogenization and microfiltration (Mistry, 2001).

In the past few years, exopolysaccharides (EPS) produced by starter strains have been proposed as a mechanism to improve the quality of reduced-fat cheeses (Awad et al., 2005a; Dabour et al., 2005; JiménezGuzmán et al., 2009). Fat reduction usually results in lower moisture in the nonfat substance (MNFS), a factor that plays a major role in texture development in cheese (Fenelon et al., 1999). Hassan (2008) suggested that EPS have the ability to bind water and increase the MNFS without the need to modify the cheesemaking procedure. This has the effect of diluting the casein matrix, increasing cheese yield and improving the texture and cooking properties of the cheese. In a recent series of studies, Rynne et al. (2007b) and Rynne (2006) found that a ropy EPS-producing starter was able to significantly increase cheese yield, coagulation proprieties, and moisture content and significantly improve functionality of half-fat Cheddar cheese; in contrast, a capsular EPS-producing culture did not have a significant effect on these parameters. However, the latter author used the EPS-producing cultures only as adjuncts, so the effects of the EPS may have been diluted. A further limitation was that the effect of different starter strains on the cheese was compared, not considering the enzymatic potential of the individual strains used regardless of EPS production.

In an earlier study, Hassan et al. (2004) used an adjunct of 2 isogenic strains of Streptococcus thermophilus in the manufacture of Karish skim milk cheese: CHCC 3534, which produced a moderately ropy EPS, and CHCC 5842, its non-EPS-producing genetic variant. The authors reported a significant difference in the moisture content and the viscoelastic properties of 
the cheese and attributed these differences to the presence of the EPS. Cheddar cheese is a viscoelastic solid in which the casein micelles of milk have undergone controlled aggregation to form a protein network that entraps fat globules and moisture. With higher levels of occluded moisture and fat, the cheese becomes less elastic and more viscous commensurate with the dilution of the casein matrix (Guinee, 2003). In a further series of studies, Hassan and Awad (2005), Hassan et al. (2005), and Awad et al. (2005a,b) investigated the effect of inclusion of EPS-producing starters and adjuncts in reduced-fat Cheddar cheese. The authors used the moderately ropy strain of $S$. thermophilus $\mathrm{CHCC}$ 3534 and its non-EPS-producing isogenic variant (CHCC 5842) as adjuncts to a lactoccocal starter and the highly ropy EPS-producing Lactococcus lactis ssp. cremoris JFR1 as a single starter, although no isogenic, non-EPS-producing variant was used.

Overall, the most significant differences were found between the control reduced-fat cheese and the reducedfat cheese made using the highly ropy EPS-producing L. lactis ssp. cremoris JFR1 as starter. Few differences were detected when the EPS-producing strains were used as an adjunct. The authors also observed that bitterness increased significantly after 2 mo of ripening when the highly ropy EPS-producing JFR1 was used as a starter culture (Awad et al., 2005a; Agrawal and Hassan, 2007). The authors attributed this bitterness to the excess moisture and residual coagulant activity (RCA) without considering the effect of the strain itself and potential different enzymatic capacities of the strains used.

To date, no study has directly compared the use of an EPS-producing and non-EPS-producing isogenic variant strain of Lactococcus lactis as single-strain starters to investigate the direct effect of the inclusion of an EPS in reduced-fat Cheddar cheese. Many of the differences reported by others may be attributed to interactive effects of strain properties (e.g., petidolytic activity, autolytic characteristics). The use of isogenic strains has the advantage of possessing the same enzymatic potential and hence the direct effect of the EPS can be more clearly elucidated. The aim of this study was to investigate the effect of inclusion of an EPS in half-fat Cheddar cheese by using single starters of a ropy EPS-producing strain of L. lactis (DPC6532) and its non-EPS-producing genetic variant (DPC6533). The cheeses were ripened for a period of 6 mo and assessed for yield, composition, texture, cooking properties, water activity, water sorption-desorption characteristics, microbiology, proteolysis, microstructure, and flavor development.

\section{MATERIALS AND METHODS}

\section{Strains}

A ropy-capsular EPS-producing strain (L. lactis ssp. cremoris DPC6532; $\mathbf{E P S}^{+}$) and its non-EPS-producing isogenic variant (L. lactis ssp. cremoris DPC6533; EPS $^{-}$) were obtained from the Moorepark Food Research Centre (Fermoy, Co. Cork, Ireland) culture collection. The $\mathrm{EPS}^{-}$variant had previously been obtained by spontaneous mutation (loss of a plasmid). Location of EPS genes and loss of the EPS plasmid by the $\mathrm{EPS}^{-}$strain were confirmed by PCR and Southern blot (data not shown). Species-specific 16s rRNA PCR was also carried out on both strains to confirm they were both from the species Lactococcus lactis. Isogenicity of strains was confirmed by pulsed field gel electrophoresis fingerprinting (data not shown).

\section{Confirmation of EPS Production and Rheological Proprieties in Milk}

Fresh 10\% reconstituted skim milks (RSM; Golden Vale Food Products Ltd., Charleville, Co. Cork, Ireland) were inoculated with $0.05 \%$ ( vol/vol) of pregrown starter strains $\left(\mathrm{EPS}^{+}\right.$and $\mathrm{EPS}^{-}$), incubated at $30^{\circ} \mathrm{C}$ for $16 \mathrm{~h}$, and assessed for ropy phenotype by the presence of threads from a loop to the surface of the culture (Hassan, 2008).

For the viscosity measurements both starter cultures were inoculated with $0.05 \%$ ( $\mathrm{vol} / \mathrm{vol}$ ) of a pregrown culture and incubated at $30^{\circ} \mathrm{C}$ in $10 \% \mathrm{RSM}$ to a $\mathrm{pH}$ of 4.5. Triplicate measurements were performed using the bob-and-cup geometry in an AR 2000 Rheometer (TA Instruments, New Castle, DE). A preshear rate of $500 / \mathrm{s}$ was applied for $1 \mathrm{~min}$, followed by a temperature equilibration time of $2 \mathrm{~min}$. A shear rate sweep from 0.1 to $500 / \mathrm{s}$ was applied for $5 \mathrm{~min}$ and the apparent viscosity $\left(\mathrm{mPa} \cdot \mathrm{s}\right.$ ) was measured at $25^{\circ} \mathrm{C}$ (Mounsey et al., 2008). The viscosity value equal to when the shear rate was at 100/s was used.

\section{Cheese Manufacture}

Raw milk was obtained from a local dairy company, standardized to a protein: fat ratio of $2.2: 1$, pasteurized at $72^{\circ} \mathrm{C}$ for $15 \mathrm{~s}$, and cooled to $31^{\circ} \mathrm{C}$ before cheesemaking. Starter cultures (L. lactis ssp. cremoris DPC6532 and DPC6533) were kept at $-80^{\circ} \mathrm{C}$ in M17 broth (Terzaghi and Sandine, 1975) containing 0.5\% lactose and $40 \%$ glycerol. Prior to cheesemaking, fresh cultures were inoculated from an active culture and grown overnight at $25^{\circ} \mathrm{C}$ in heat-treated $\left(90^{\circ} \mathrm{C}\right.$ for $\left.30 \mathrm{~min}\right)$, reconsti- 
tuted, antibiotic-free 10\% RSM until a pH of 4.9 was reached.

Cheddar cheeses were produced in triplicate using a standard cheesemaking procedure (Rynne et al., 2004) using a $1.5 \%$ inoculum of each starter and were cut at a standardized gel firmness of $35 \mathrm{~Pa}$ (gel firmness was measured as described in the following section). Cheeses were vacuum packed and ripened at $8^{\circ} \mathrm{C}$ for 6 mo.

\section{Rennet Coagulation Properties}

The elastic shear modulus $\left(\mathbf{G}^{\prime}\right)$ was monitored by placing a $10-\mathrm{mL}$ sample of the renneted milk in a controlled-stress rheometer ( $\mathrm{CSL}^{2}$ Carri-Med; TA Instruments) at $31^{\circ} \mathrm{C}$ with low amplitude oscillation as described previously (Guinee et al., 1996). The gelation time (GT) was defined as the time taken for $\mathrm{G}^{\prime}$ to reach a value of $\geq 0.2 \mathrm{~Pa}$ and set-to-cut time (SCT) as the time to reach a $\mathrm{G}^{\prime}$ of $35 \mathrm{~Pa}$ (gel cutting firmness for all cheese vats. The latter parameters were determined by fitting the Scott Blair equation, $\mathrm{G}=\mathrm{Ge}^{-\lambda /(\mathrm{t}-\tau)}$, to the rheometric data (O'Callaghan and Guinee, 1995). This was done using $\mathrm{G}^{\prime}$ measurements from $120 \mathrm{~s}$ after rennet addition until $\mathrm{G}^{\prime}$ reached $35 \mathrm{~Pa}$ and then adjusting the $\mathrm{G}, \lambda$, and $\tau$ to fit the data in a least squares sense using the Solver utility tool with Microsoft Excel software (version 7.0a, Microsoft Corp., Redmond, WA).

\section{Acidification Curves}

The $\mathrm{pH}$ was measured in the initial milk and in the curd at intervals from the beginning of manufacture until the end. Curd $\mathrm{pH}$ was measured by inserting the probe into a piece of curd while gently pressing to release the whey (Scott et al., 1998).

\section{Calculation of Cheese Yields}

Actual cheese yield $\left(\mathbf{Y}_{\mathbf{a}}\right)$, expressed as kilograms of cheese obtained per $100 \mathrm{~kg}$ of milk, was obtained by weighing the amount of milk used and cheese obtained after pressing. Actual cheese yield was also expressed as actual yield per $100 \mathrm{~kg}$ of cheese milk normalized to reference levels of fat $(1.5 \%$, wt/wt) and protein $(3.3 \%$, wt/wt; $\left.\mathbf{Y}_{\text {afpam }}\right)$ to eliminate intertrial differences. The $\mathrm{Y}_{\text {mafpam }}$, moisture-adjusted cheese yield per $100 \mathrm{~kg}$ of cheese milk adjusted to reference levels of fat $(3.4 \%$, $\mathrm{wt} / \mathrm{wt})$, protein $(3.3 \%$, wt/wt), and moisture $(38.5 \%$, wt/wt), was also calculated and expressed as kilograms per $100 \mathrm{~kg}$ of normalized cheese milk. Further details on the calculation of the yields can be found in Guinee et al. (2006).

\section{Cheese Sampling}

Cheeses were samples at various times throughout ripening (at d 1, 14, 28, 60, 120, and 180). At each sampling time, a 7 - to $8-\mathrm{cm}$ slab of cheese was cut from the exterior face of the block; the outer layer $(1-2 \mathrm{~cm})$ of the slab was discarded and the remainder was used for analysis.

\section{Cheese Composition}

Cheese samples at $28 \mathrm{~d}$ were grated and analyzed in triplicate for $\mathrm{pH}$ (British Standards Institution, 1976), moisture (International Dairy Federation, 1982), fat (International Dairy Federation, 1986), protein (International Dairy Federation, 2001), sodium chloride (International Dairy Federation, 1981), ash (International Dairy Federation, 1964), and calcium (International Dairy Federation, 1984).

\section{Assessment of Proteolysis in Cheese}

pH 4.6-Soluble Nitrogen and Reverse PhaseHPLC Analysis. Total nitrogen was determined by the macro-Kjeldahl method (International Dairy Federation, 1993). The levels of $\mathrm{pH} 4.6$-soluble nitrogen (pH 4.6-SN) were determined in triplicate using the method of Kuchroo and Fox (1982) and expressed as a percentage of total nitrogen.

The profile of peptides of each $\mathrm{pH}$ 4.6-SN fraction was analyzed as described in Fenelon et al. (2000).

Individual Free $\boldsymbol{A} \boldsymbol{A}$. Individual free AA (FAA) were determined in duplicate on the $\mathrm{pH}$ 4.6-SN extracts as described by Fenelon et al. (2002) using a Jeol JLC-500V AA analyzer fitted with a Jeol $\mathrm{Na}^{+}$highperformance cation exchange column (Jeol Ltd., Tokyo, Japan). The chromatographic analyses were conducted at $\mathrm{pH} 2.2$ on d 1, 14, 28, 56, 112, and 168. Results were expressed as parts per million $(\mu \mathrm{g} / \mathrm{g})$.

\section{Cryogenic Scanning Electron Microscopy}

Cryogenic scanning electron microscopy (cryo-SEM) was performed using a modification of the method of Rößle et al. (2009). Briefly, thin sections of cheese samples $(1 \mathrm{~mm} \times 1 \mathrm{~mm} \times 4 \mathrm{~mm})$ at $\mathrm{d} 1$ of ripening were frozen in liquid nitrogen slush at $-207^{\circ} \mathrm{C}$ followed by freeze fracturing under vacuum using a precooled scalpel blade. The fractured surfaces were then etched at $-80^{\circ} \mathrm{C}$ for $15 \mathrm{~min}$, cooled to $-125^{\circ} \mathrm{C}$, and coated with sputtered platinum (10 mA for $60 \mathrm{~s})$. Samples were transferred under vacuum to the cold stage in a 
Zeiss Supra 40VP scanning electron microscope (Carl Zeiss AG, Darmstadt, Germany), where they were maintained at $-125^{\circ} \mathrm{C}$ and imaged using an accelerating voltage of $1 \mathrm{kV}$.

\section{Texture Profile Analysis}

Cheeses samples $\left(25 \mathrm{~mm}^{3}\right.$ cubes $)$ were cut from the slab of cheese (Cheese Blocker; Bos Kaasgreedschap, Bodengraven, Netherlands) and stored at $4^{\circ} \mathrm{C}$ overnight before analysis. Texture was assessed on d 1, 14, 28, 56,112 , and 168 by compression on a texture analyzer (model TA-HDI, Stable Micro Systems, Godalming, UK) with a $5-\mathrm{mm}$ compression plate and a 100-kg load cell. Each sample was subjected to 2 consecutive compressions at a speed of $1 \mathrm{~mm} / \mathrm{s}$, each to $30 \%$ of original sample height, as described in Rynne et al. (2004). Texture profile analysis parameters were calculated as described previously (Bourne, 1978). Hardness (N) was measured as the force at maximum compression on the first bite. Fracture stress (KPa) was measured as the force per unit area at the point of fracture on the first bite, and fracture strain (dimensionless) was measured as the strain corresponding to the minimum slope on the force-displacement curve. Cohesiveness (dimensionless) was calculated as the ratio of the area of the second bite to that of the first bite. Springiness (dimensionless) was calculated as the ratio of distance of the second bite (peak) to the distance of the first bite (peak), and chewiness $(\mathrm{N})$ was calculated as the product of hardness $\times$ cohesiveness $\times$ springiness. Adhesiveness $(\mathrm{N} \cdot \mathrm{s})$ was calculated as the negative area after the first bite in the texture profile curve as described in Van Vliet (1991), Bourne (1978), and Szczesniak et al. (1963) and expressed in absolute values.

\section{Physical Characteristics of the Heated Cheese}

Flowability was assessed using 2 different methods. The first method consisted of a modification of the Schreiber method as described by Guinee et al. (2002). The second method consisted of a modification of the Olson-Price method as described by Rynne et al. (2004). Flowability was assessed on d 1, 14, 28, 56, 112, and 168.

Apparent viscosity at $70^{\circ} \mathrm{C}$ of the molten cheese was measured at d 168 as described previously (Guinee et al., 2000) using a helipath viscometer (Brookfield, Mode DV-II, Brookfield Engineering Laboratories Inc., Stoughton, MA) set at $5 \mathrm{rpm}$.

Viscoelastic changes of cheeses, on heating from 20 to $90^{\circ} \mathrm{C}$, were monitored on d 168 in a controlled-stress rheometer (CSL ${ }^{2}$ Carri-Med, TA Instruments) as previously described by Guinee et al. (1999).

\section{Water Activity and Dynamic Water Vapor Sorption-Desorption in the Cheese}

The water activity $\left(\mathbf{a}_{\mathrm{w}}\right)$ of cheeses was analyzed in triplicate on approximately $3 \mathrm{~g}$ of grated cheese on an Aqualab water activity meter (Series $3 \mathrm{TE}$ Water Activity Meter, Labcell Ltd., Hampshire, UK) at $25^{\circ} \mathrm{C}$ as described by the manufacturer's instructions. The $\mathrm{a}_{\mathrm{w}}$ was measured on d 1, 56, 84, 112, 140, and 168 .

For the dynamic water vapor sorption-desorption analysis, 500-mg cheese samples were removed from the center of the cheese block using a small cylindrical trier (5 mm diameter) and placed in an automatic multisample moisture analyzer (SPS11, Project-Messtechnik, Ulm, Germany) at $15^{\circ} \mathrm{C}$. Cheeses were analyzed in triplicate at $168 \mathrm{~d}$ for moisture loss (desorption) followed by moisture uptake (adsorption) as a function of relative humidity (RH) in the range of 0 to $90 \%$. The atmosphere in the enclosed chamber of the analyzer containing the cheese was initially equilibrated at $90 \%$ RH. Once the samples and atmosphere had equilibrated, the relative humidity was decreased stepwise by increments of approximately $10 \% \mathrm{RH}$, from 90 to $0 \%$, with sufficient time (12 h) at each $\mathrm{RH}$ to allow equilibration of sample weight loss. Thereafter, the RH was increased from 0 to $90 \%$ in similar increments. The change in sample mass at the different $\mathrm{RH}$ values was dynamically recorded by the internal instrument balance at 5 -s intervals. The samples were analyzed in triplicate at $d$ 168 of ripening.

\section{Microbiological Analysis and Autolysis}

Microbiological analysis of the cheeses and lysis of the starter cultures were performed on d 1, 14, 28, 56, 84, 112,140 , and 168 of ripening as described by Hannon et al. (2005, 2006a). Starter lactic acid bacteria were enumerated in LM17 agar (Terzaghi and Sandine, 1975) for $3 \mathrm{~d}$ and nonstarter lactic acid bacteria (NSLAB) were incubated anaerobically with an overlay for $5 \mathrm{~d}$ on Lactobacillus selective agar (LBS agar; Rogosa et al., 1951).

Autolysis of starter cultures in cheese during ripening was monitored by assaying in triplicate for the intracellular enzyme lactate dehydrogenase (LDH) released into the cheese juice. The LDH activity was assayed by method of Cogan et al. (1981). The results were expressed as units per $0.1 \mathrm{~mL}$ of extract, where 1 unit is defined as the amount of enzyme that is required to catalyze the oxidation of $1 \mu M$ of $\mathrm{NADH} / \mathrm{min}$.

\section{Flavor Analysis}

FFA Analysis. Free fatty acids in cheese were determined by gas chromatography with flame ionization 
detection at d 168 using a previously described method (De Jong and Badings, 1990) as modified by Hickey et al. (2006). All samples were analyzed in duplicate.

Volatile Analysis. For volatile analysis, $5 \mathrm{~g}$ of each cheese sample was added to $20-\mathrm{mL}$ solid-phase microextraction (SPME) vials and analyzed in triplicate. All injections were made on an Agilent 6890N GC (Agilent Technologies, Palo Alto, CA) with 5973 inert mass selective detector with a DB-5ms column $(30 \mathrm{~m} \times 0.25$ $\mathrm{mm}$ i.d. $\times 0.25 \mu \mathrm{m})$. Sample introduction was accomplished using a CTC Analytics CombiPal Autosampler (Zwingen, Switzerland). An internal standard solution (2-methyl-3-heptanone made up in methanol) was added at $162 \mathrm{ppb}$. Vials were equilibrated for $25 \mathrm{~min}$ at $40^{\circ} \mathrm{C}$ with pulsed agitation of $4 \mathrm{~s}$ at $250 \mathrm{rpm}$. A single divinylbenzene/Carboxen/ polydimethylsiloxane 1-cm fiber was used for all analysis. The SPME fiber was exposed to the samples for $30 \mathrm{~min}$ at a depth of $2.1 \mathrm{~cm}$. The fiber was retracted and injected into the $\mathrm{GC}$ inlet and desorbed for $5 \mathrm{~min}$. Compounds were identified using mass spectra comparisons with the NIST 2005 mass spectral library. Relative intensities of each compound were compiled from total ion counts for each peak of interest compared with the peak area of the internal standard. Average values (ppb relative to internal standard) for the compounds identified were compiled (SPME headspace volatile compound relative abundance of select compounds; $\mu \mathrm{g} / \mathrm{L}$ ).

Sensory Analysis. Cheeses from each trial were subjected to descriptive sensory analysis after $165 \mathrm{~d}$ of ripening. Sensory testing was conducted in compliance with North Carolina State University Institutional Review Board for Human Subjects approval (Drake et al., 2005). Cheddar cheeses were cut into 2 -cm cubes for descriptive sensory analysis. The cheeses were placed into $58-\mathrm{mL}$ soufflé cups and given a 3 -digit code. The cheeses were tempered at $10^{\circ} \mathrm{C}$ for $1 \mathrm{~h}$ and were served at this temperature with spring water and unsalted crackers for palate cleansing. Descriptive analysis of flavor used a 15-point universal intensity scale with the Spectrum method (Meilgaard et al., 1999; Drake and Civille, 2003) and a previously established cheese flavor sensory language (Drake et al., 2001; CarunchiaWhetstine et al., 2003; Drake et al., 2005). A trained descriptive sensory panel $(\mathrm{n}=10,9$ females, 1 male, ages 22-46) with more than $200 \mathrm{~h}$ of experience with the descriptive analysis of Cheddar cheese flavor evaluated the cheeses. The cheeses were assessed for the following favor attributes: cooked, whey, milkfat, sulfur, brothy, nutty, cowy, mothball, sweet, sour, bitter, salty, and umami. Descriptive analysis of cheese texture attributes was conducted using a separate panel $(\mathrm{n}=$ 8, 8 females, ages 46-56), each with more than 1,000 $\mathrm{h}$ of experience with the descriptive analysis of food flavor and texture. Descriptive analysis of texture used a 15-point product-specific intensity scale (Meilgaard et al., 1999; Drake and Civille, 2003) and a previously established cheese texture sensory language (Brown et al., 2003). The cheeses were assessed for the following textural attributes: hand firmness (Hfirmness), hand springiness (HSpringiness), hand rate of recovery (Hrate of recovery), firmness, fracturability, degree of breakdown, cohesiveness, smoothness of mass, and smoothness of mouthcoating (smoothness of mthct). Each panelist evaluated each cheese from each treatment replication in duplicate.

\section{Experimental Design and Statistical Analysis}

Three replicate cheesemaking trials were undertaken with 2 cheeses produced in each trial (1 with the EPS ${ }^{+}$ starter and 1 with the $\mathrm{EPS}^{-}$starter). All statistical analyses were carried out using SAS (version 9.1.3, SAS Institute, Cary, NC).

A randomized complete block design that incorporated the 2 treatments (starters) and 3 blocks (replicate trials) was used for the analysis of response variables relating to the composition of cheeses, rheology data, cheese yields, FFA, sorption assay, and apparent viscosity. Analysis of variance was carried out on data using the general linear model procedure of SAS (SAS Institute). The Tukey honestly significant difference test was used to determine the significance of difference between the means. The level of significance was determined at $P<0.05$.

A split-plot design was used to monitor the effects of treatment (starter culture) and ripening time and their interaction on the response variables measured at regular intervals during ripening (textural parameters, melting properties, LDH, water activity, starter and NSLAB counts, pH4.6-SN, and FAA). Analysis of variance for the split-plot design was carried out on data using the mixed procedure of SAS (SAS Institute). Statistically significant differences $(P<0.05)$ between different treatment levels were determined by using Fisher's least significant difference. Analysis of variance was also applied to the sensory analysis data using Fisher's least significant difference to characterize differences in descriptive attributes between the cheeses using SAS (SAS Institute).

\section{RESULTS AND DISCUSSION}

\section{Confirmation of EPS Production and Rheological Proprieties in Milk}

The $\mathrm{EPS}^{+}$strain showed a high level of ropiness in $10 \%$ RSM (Figure 1), whereas no ropiness was observed 


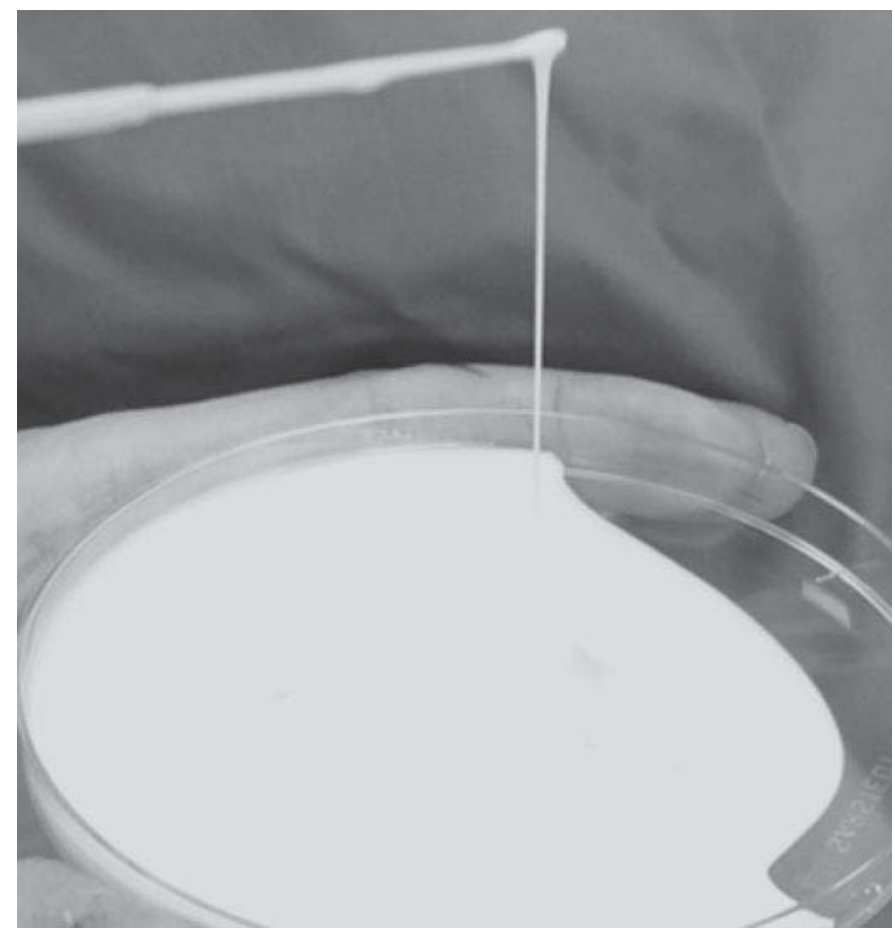

Figure 1. Ropiness of the exopolysaccharide-producing strain Lactococcus lactis ssp. cremoris DPC 6532 grown on 10\% reconstituted skim milk.

for the $\mathrm{EPS}^{-}$strain. Also, the $\mathrm{EPS}^{+}$strain grown in $10 \%$ RSM exhibited a significantly $(P<0.001)$ higher viscosity $\left(\right.$ at $25^{\circ} \mathrm{C}$ ) than the $\mathrm{EPS}^{-}$strain $(38.6 \pm 1.0$ $\mathrm{mPa} \cdot \mathrm{s}$ for the $\mathrm{EPS}^{-}$strain and $122.8 \pm 1.1 \mathrm{mPa} \cdot \mathrm{s}$ for the $\mathrm{EPS}^{+}$strain), confirming the production of EPS in RSM media.

\section{Acidification Profiles of the Strains During Cheesemaking}

The average acidification profiles for the $\mathrm{EPS}^{+}$and the EPS $^{-}$cheese manufactures are shown in Figure 2. No significant differences were found between the acidification rates of the 2 strains, as was expected because of their isogenicity.

\section{Effect of EPS on Rennet Coagulation During Cheesemaking}

The presence of the EPS did not significantly alter the rennet coagulation properties GT and SCT. Similar mean values for both variables were obtained: the GT was 20.08 min for the $\mathrm{EPS}^{+}$strain and $22.47 \mathrm{~min}$ for the $\mathrm{EPS}^{-}$strain, and the SCT at $35 \mathrm{~Pa}$ was $50.06 \mathrm{~min}$ for the $\mathrm{EPS}^{+}$strain and 50.01 min for the EPS ${ }^{-}$strain. In contrast to the results of this study, Hassan and Frank
(1997) showed that the presence of an EPS-producing culture (S. thermophilus S3855) significantly impaired curd tension and firmness. However, Rynne et al. (2007b) reported that the GT and SCT values decreased on inclusion of a ropy EPS-producing adjunct culture $(L$. lactis ssp. cremoris 322), but no significant differences were observed when a capsular EPS-producing adjunct culture (S. thermophilus MR-1C) was added. Because the strains used in this study were isogenic (differing only in their ability to produce an EPS) and considered to have the same enzymatic potential and acidification capacity, all differences observed were considered to be attributable to the presence of the EPS. However, no significant differences were observed in the coagulation parameters (GT and SCT) and, hence, the presence of the EPS in the current study was considered not to interfere with the coagulation rate for this strain.

\section{Cheese Yield}

Cheese yields are shown in Table 1 . The $\mathrm{Y}_{\mathrm{a}}$ increased significantly $(P<0.001)$ by $8.17 \%$ in the $\mathrm{EPS}^{+}$cheese compared with the EPS ${ }^{-}$cheese, in agreement with previous studies (Awad et al., 2005a; Dabour et al., 2005; Rynne et al., 2007b). The $\mathrm{Y}_{a}$ of the $\mathrm{EPS}^{-}$cheese was similar to that previously reported for half-fat Cheddar cheese (Fenelon and Guinee, 1999). To eliminate any intertrial differences in milk composition, cheese yield was also expressed as $Y_{\text {afpam. }}$. Again, the $Y_{\text {afpam }}$ was significantly $(P<0.001)$ higher for the $\mathrm{EPS}^{+}$cheese (8.34\%). Adjusting the $\mathrm{Y}_{\text {afpam }}$ to a reference moisture level of $38.5 \%$ ( $Y_{\text {mafpam }}$ ) highlights whether differences observed in the actual yield were attributable to differences in the moisture content. No significant differences were detected between the cheeses for a reference moisture level of $38.5 \%$, which confirmed that the increase in yield was attributable to the increase in moisture caused by the presence of the EPS.

\section{Cheese Composition}

The composition of the cheeses is shown in Table 1. In agreement with the results of this study, Awad et al. (2005a), Guinee et al. (2000), and Dabour et al. (2005) also reported that reduced-fat Cheddar cheeses had high moisture and protein contents, reduced fat in DM, MNFS, and salt in moisture $(\mathbf{S} / \mathbf{M})$ compared with full-fat Cheddar cheese. The inclusion of the EPS significantly $(P<0.001)$ increased the moisture content (by $9.49 \%$ ), again concurring with previous studies (Awad et al., 2005a; Dabour et al., 2005; Rynne et al., 2007b). This may result from the trapping of the water by the EPS through hydrogen binding. As a consequence of the higher moisture, the $\mathrm{S} / \mathrm{M}$ is significantly $(P<$ 
Table 1. Cheese yields and composition of half-fat Cheddar cheese manufactured with $\mathrm{EPS}^{+}$and $\mathrm{EPS}^{-}$starters $^{1}$ at d 28 of ripening

\begin{tabular}{|c|c|c|}
\hline \multirow[b]{2}{*}{ Composition $^{2}$} & \multicolumn{2}{|c|}{ Starter } \\
\hline & $\mathrm{EPS}^{+}$ & $\mathrm{EPS}^{-}$ \\
\hline Moisture (\%,wt/wt) & $46.11^{\mathrm{a}}$ & $41.74^{\mathrm{b}}$ \\
\hline Fat $(\%, w t / w t)$ & $15.79^{\mathrm{a}}$ & $17.17^{\mathrm{b}}$ \\
\hline Protein $(\%, w t / w t)$ & $32.90^{\mathrm{a}}$ & $33.86^{\mathrm{a}}$ \\
\hline Salt $(\%, w t / w t)$ & $1.73^{\mathrm{a}}$ & $1.86^{\mathrm{a}}$ \\
\hline $\operatorname{Ash}(\%, w t / w t)$ & $4.23^{\mathrm{a}}$ & $4.73^{\mathrm{a}}$ \\
\hline $\mathrm{Ca}(\mathrm{mg} / 100 \mathrm{~g})$ & $907^{\mathrm{a}}$ & $1,023^{\mathrm{b}}$ \\
\hline $\mathrm{pH}$ & $5.14^{\mathrm{a}}$ & $5.36^{\mathrm{b}}$ \\
\hline MNFS $(\%, w t / w t)$ & $54.28^{\mathrm{a}}$ & $50.80^{\mathrm{b}}$ \\
\hline FDM $(\%, w t / w t)$ & $28.91^{\mathrm{a}}$ & $29.81^{\mathrm{a}}$ \\
\hline $\mathrm{S} / \mathrm{M}(\%, \mathrm{wt} / \mathrm{wt})$ & $3.75^{\mathrm{a}}$ & $4.45^{\mathrm{b}}$ \\
\hline Calcium:protein ratio $(\mathrm{mg} / \mathrm{g})$ & $28.68^{\mathrm{a}}$ & $29.20^{\mathrm{a}}$ \\
\hline $\mathrm{Y}_{\mathrm{a}}(\%)$ & $8.02^{\mathrm{a}}$ & $7.42^{\mathrm{b}}$ \\
\hline$Y_{\text {afpam }}(\%)$ & $8.33^{\mathrm{a}}$ & $7.69^{\mathrm{b}}$ \\
\hline$Y_{\text {mafpam }}(\%)$ & $7.38^{\mathrm{a}}$ & $7.25^{\mathrm{a}}$ \\
\hline
\end{tabular}

${ }^{\mathrm{a}, \mathrm{b}}$ Values within a row not sharing a common superscript differ significantly $(P<0.05)$.

${ }^{1} \mathrm{EPS}^{+}=$cheese manufactured with a starter producing an exopolysaccharide (EPS); $\mathrm{EPS}^{-}=$cheese manufactured with a starter not producing an EPS.

${ }^{2} \mathrm{MNFS}=$ moisture in the nonfat substances; FDM $=$ fat in DM; S/M $=$ salt in moisture; $Y_{\mathrm{a}}=\mathrm{kg}$ of cheese per $100 \mathrm{~kg}$ of milk; $\mathrm{Y}_{\mathrm{afpam}}=\mathrm{kg}$ of cheese obtained per $100 \mathrm{~kg}$ of milk normalized to a reference level of $1.5 \%$ (wt/wt) fat and $3.3 \%$ (wt/wt) protein; $\mathrm{Y}_{\operatorname{mafpam}}=$ moistureadjusted cheese yield per $100 \mathrm{~kg}$ of cheese milk adjusted to reference levels of fat $(3.4 \%, \mathrm{wt} / \mathrm{wt})$, protein $(3.3 \%, \mathrm{wt} / \mathrm{wt})$, and moisture $(38.5 \%, \mathrm{wt} / \mathrm{wt})$.

0.001) lower in the $\mathrm{EPS}^{+}$cheese. Previous studies have also reported that cheeses made using EPS-producing cultures have a higher MNFS $(P<0.001)$ compared with control cheese made using non-EPS-producing cultures (Dabour et al., 2005; Rynne et al., 2007b). Despite the $\mathrm{EPS}^{+}$cheese having a lower level of fat (15.79\%; $P<0.05)$ compared with the $\mathrm{EPS}^{-}$cheese (17.17\%), the fat in DM was not significantly different. This is thought to be attributable to the dilution effect on all DM components at the higher moisture levels in the cheese made using the $\mathrm{EPS}^{+}$culture (Rynne et al., 2007b).

The $\mathrm{pH}$ of the $\mathrm{EPS}^{+}$cheese was significantly lower than that of the $\mathrm{EPS}^{-}$cheese despite the fact that the curds for both cheeses were drained and milled at similar $\mathrm{pH}$ values ( $\mathrm{pH} 6.15$ and 5.35, respectively). The EPS may have had a protective effect on the bacterial cells after salting, which could have resulted in a greater salt tolerance, allowing the $\mathrm{pH}$ to further decrease during pressing. This is consistent with Rynne et al. (2007a), who reported that high-moisture, reduced-fat Cheddar cheeses have lower $\mathrm{pH}$ values than their low-moisture controls because of a higher concentration of lactose, and hence, lactic acid in the cheese, and the attendant increase in the lactate:buffering capacity ratio. The calcium content of the $\mathrm{EPS}^{+}$cheese was lower $(P<$ 0.001) than that of the $\mathrm{EPS}^{-}$cheese despite the $\mathrm{pH}$ being similar for both cheeses at the different stages of manufacture. This effect could simply be attributed to the higher moisture content of the $\mathrm{EPS}^{+}$cheese having a diluting effect on the calcium and also to the decrease of $\mathrm{pH}$ during pressing observed for the $\mathrm{EPS}^{+}$cheese, resulting in part of the micellar calcium phosphate being

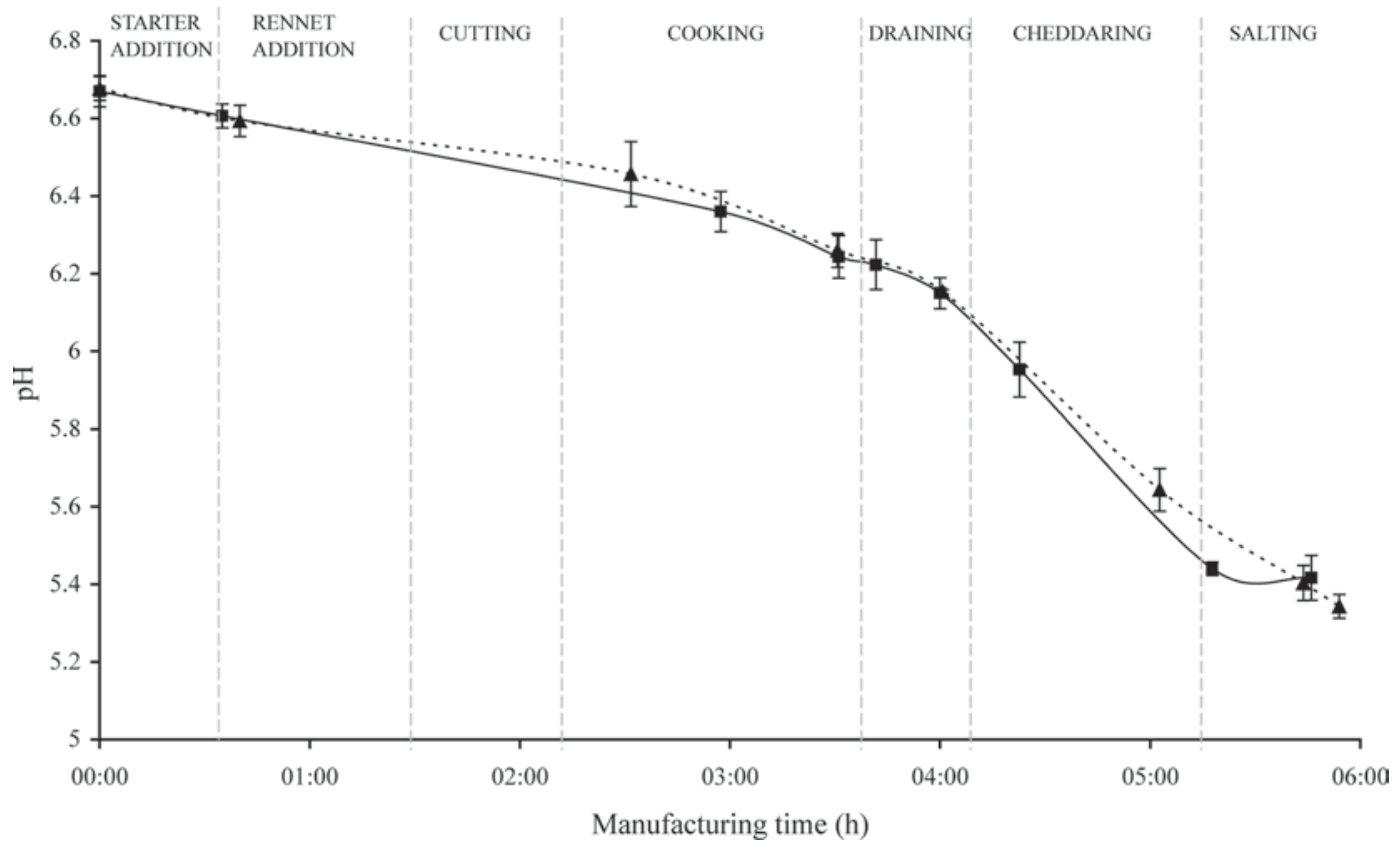

Figure 2. Acidification profiles of the exopolysaccharide-producing strain ( $\mathbf{\square}$; continuous line) and non-exopolysaccharide-producing strain ( $\mathbf{\Lambda}$; dotted line) during cheese manufacture. Approximate timing of the different manufacturing steps is indicated by vertical dashed lines. 
Table 2. Levels of $\mathrm{pH}$ 4.6-soluble nitrogen and free AA during ripening of half-fat Cheddar cheeses manufactured with $\mathrm{EPS}^{+}$and $\mathrm{EPS}^{-}$starters $^{1}$

\begin{tabular}{lcr}
\hline & \multicolumn{2}{c}{ Treatment } \\
\cline { 2 - 3 } Ripening time (d) & $\mathrm{EPS}^{+}$ & $\mathrm{EPS}^{-}$ \\
\hline $\mathrm{pH} 4.6-\mathrm{SN}^{2}$ (\% of total N) & $5.12^{\mathrm{a}, \mathrm{A}}$ & $4.59^{\mathrm{b}, \mathrm{A}}$ \\
1 & $7.69^{\mathrm{a}, \mathrm{B}}$ & $6.58^{\mathrm{b}, \mathrm{B}}$ \\
14 & $10.77^{\mathrm{a}, \mathrm{C}}$ & $8.56^{\mathrm{b}, \mathrm{C}}$ \\
28 & $15.55^{\mathrm{a}, \mathrm{D}}$ & $13.28^{\mathrm{b}, \mathrm{D}}$ \\
56 & $23.28^{\mathrm{a}, \mathrm{E}}$ & $21.31^{\mathrm{b}, \mathrm{E}}$ \\
112 & $26.95^{\mathrm{a}, \mathrm{F}}$ & $24.18^{\mathrm{b}, \mathrm{F}}$ \\
168 & & \\
Free AA ( $\mu \mathrm{g} / \mathrm{g}$ of cheese) & $1,277.33^{\mathrm{a}, \mathrm{A}}$ & $1,014.81^{\mathrm{b}, \mathrm{A}}$ \\
1 & $1,789.82^{\mathrm{a}, \mathrm{B}}$ & $1,689.26^{\mathrm{a}, \mathrm{B}}$ \\
14 & $2,086.95^{\mathrm{a}, \mathrm{C}}$ & $2,063.37^{\mathrm{a}, \mathrm{C}}$ \\
28 & $2,843.81^{\mathrm{a}, \mathrm{D}}$ & $3,484.59^{\mathrm{b}, \mathrm{D}}$ \\
56 & $5,535.27^{\mathrm{a}, \mathrm{E}}$ & $6,349.98^{\mathrm{b}, \mathrm{E}}$ \\
112 & $6,790.00^{\mathrm{a}, \mathrm{F}}$ & $7,313.99^{\mathrm{a}, \mathrm{F}}$ \\
\hline
\end{tabular}

${ }^{\mathrm{a}, \mathrm{b}}$ Values within a row not sharing a common superscript differ significantly $(P<0.001)$.

${ }^{\mathrm{A}, \mathrm{F}}$ Values within a column not sharing a common superscript differ significantly $(P<0.001)$.

${ }^{1} \mathrm{EPS}^{+}=$cheese made with a starter producing an exopolysaccharide (EPS), $\mathrm{EPS}^{-}=$cheese made with a starter not producing an EPS.

${ }^{2} \mathrm{pH} 4.6-\mathrm{SN}=$ nitrogen soluble in water at $\mathrm{pH} 4.6$.

solubilized and released with the press whey. However, the calcium:protein ratio was not significantly different between the cheeses despite being numerically lower in the $\mathrm{EPS}^{+}$cheese.

\section{Proteolysis}

Primary Proteolysis. Primary proteolysis, as measured by the pH4.6-SN expressed as a percentage of total nitrogen (Table 2), increased significantly $(P<$ 0.001 ) in all cheeses during ripening and is thought to be attributable to the continuous degradation of casein to low molecular weight water-soluble peptides and AA by the action of the residual coagulant and the proteolytic activity of the cheese starter culture (Sallami et al., 2004; Awad et al., 2005a; Dabour et al., 2006). Significantly higher $(P<0.001)$ levels of proteolysis were detected in the $\mathrm{EPS}^{+}$cheese compared with the EPS ${ }^{-}$cheese, consistent with previous studies (Awad et al., 2005a). The latter authors reported that cheeses made using EPS-producing cultures retain more moisture and have a higher RCA and therefore have higher pH4.6-SN. The EPS ${ }^{+}$cheese had a higher moisture content and possibly higher RCA, which may have caused the increase in primary proteolysis.

It has previously been reported that Cheddar cheese made with EPS cultures can develop high levels of bitterness after 2 or 3 mo of ripening (Awad et al., 2005a; Agrawal and Hassan, 2007), as shown by both flavor analysis and the presence of high levels of late-eluting peaks on the reverse phase-HPLC chromatograms. These studies attributed the bitterness to the extra moisture content, RCA, and low $\mathrm{S} / \mathrm{M}$ in the cheese made with an EPS-producing adjunct. However, the peptide profile at 6 mo of ripening for both cheeses (data not shown) in this study was very similar despite the $\mathrm{EPS}^{+}$cheese having higher moisture content and lower S/M; the $\mathrm{EPS}^{+}$cheese did not contain more bitter peptides than the $\mathrm{EPS}^{-}$cheese. Again, the levels of bitterness reported by these authors for cheese manufactured with EPS cultures may be attributable to the enzymatic potentials of the individual strains used in the studies rather than to the presence of the EPS.

$\boldsymbol{F A} \boldsymbol{A}$. The levels of total free AA (Table 2) were similar to those previously reported for full-fat Cheddar cheese (Hannon et al., 2003) and increased significantly $(P<0.001)$ as ripening progressed. The $\mathrm{EPS}^{+}$cheese had significantly higher $(P<0.05)$ levels of total FAA compared with the $\mathrm{EPS}^{-}$cheese at $\mathrm{d} 1$ of ripening. However, after 2 mo of ripening, the levels of total FAA were higher $(P<0.05)$ in the $\mathrm{EPS}^{-}$cheese despite both cheeses having similar levels of lysis and starter-NSLAB counts. This observation was similar to the studies of Awad et al. (2005a) and Agrawal and Hassan (2007), who reported a much slower rate of accumulation of FAA in cheese made using a ropy strain of Lactococcus lactis ssp. cremoris (RF-JFR1). In these last 2 studies the cheeses compared were produced with different strains (EPS-producing and non-EPS-producing), so the different enzymatic potential of the individual strains may also have contributed to the differences in the levels of FAA. However, in this study all differences observed should be attributed to the presence of the EPS. The results of Awad et al. (2005a) and Agrawal and Hassan (2007) as well as this study have shown that the cheeses made with an EPS starter culture have lower levels of secondary proteolysis, which suggests that the presence of an EPS may hinder the transport of peptides, or substrates, or both in and out of the cell or may be impairing the access of peptidases to their substrates in the curd on cell lysis.

\section{Cryo-SEM}

The microstructures of the 1-d-old cheeses are shown in Figure 3. The $\mathrm{EPS}^{+}$cheese (Figure 3A) had a more porous, uneven structure with large and more numerous cavities. The heterogeneous matrix is believed to be attributable to the presence of the EPS, which is excreted from the bacterial cells into the surrounding protein matrix, forming a porous network because of the filamentous nature of the ropy EPS (Figure 3B). Ayala-Hernandez et al. (2008) recently confirmed using 

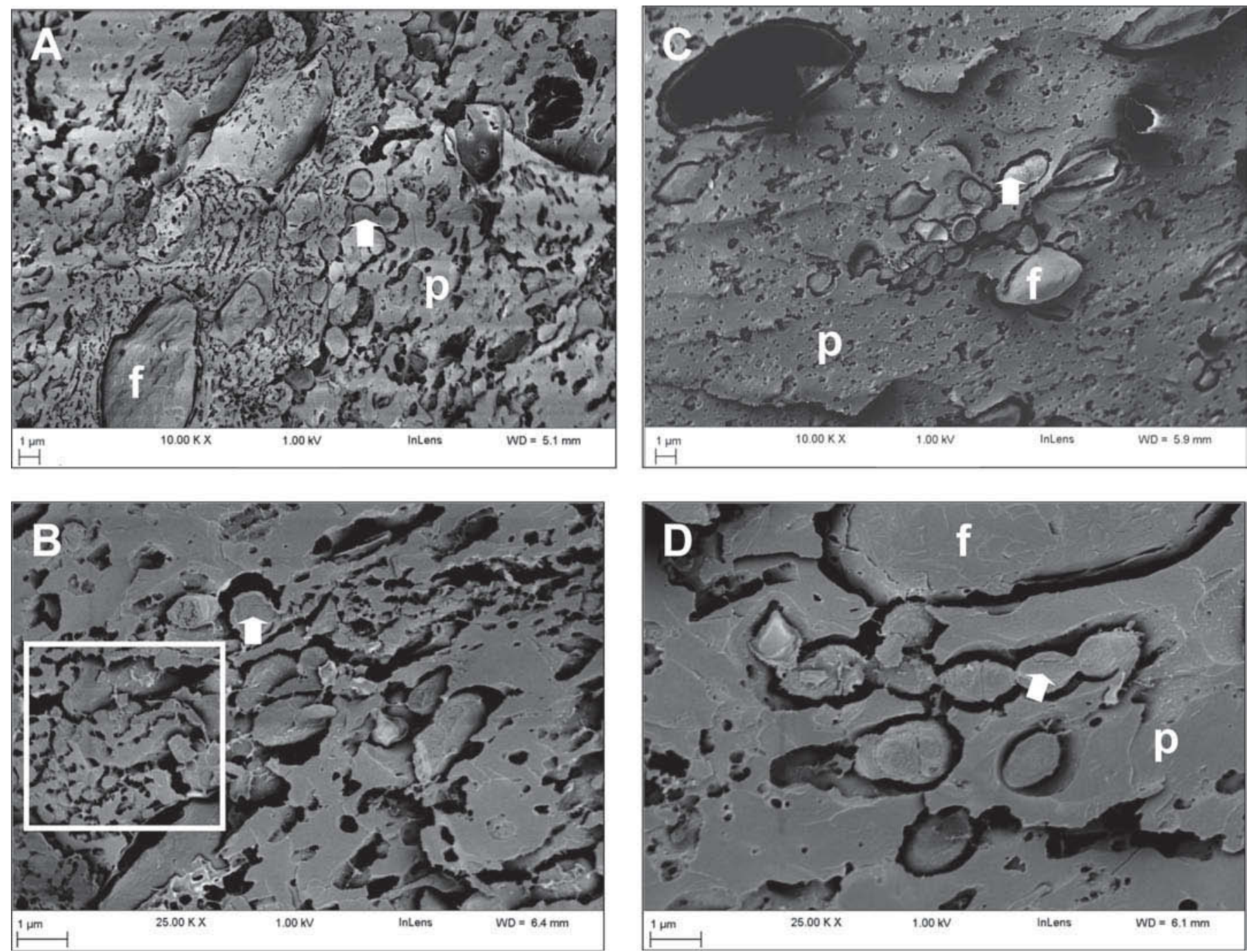

Figure 3. Cryogenic-scanning electron micrographs of 1-d-old half-fat Cheddar cheeses manufactured using either an exopolysaccharide (EPS)-producing culture (A and B) or its isogenic non-EPS-producing variant $(\mathrm{C}$ and $\mathrm{D})$. Arrow indicates bacterial cells; square indicates the network areas of protein-EPS interaction; $\mathrm{f}=$ fat globule; $\mathrm{p}=$ protein.

SEM that some EPS can interact with dairy proteins (both caseins and whey proteins). This porous network was not observed to be uniform throughout the cheese matrix and was considered to be attributable to presence of the EPS being expressed from bacterial colonies that were nonuniformly distributed within the matrix as the gel formed. The cavities in this highly porous network (initially caused by the presence of the EPS) may have retained the extra moisture and further contributed to a more open structure (Hassan and Awad, 2005; Rynne, 2006).

The matrix in the $\mathrm{EPS}^{-}$cheese (Figure 3C) was seen to be more dense, contained fewer cavities, and was more homogeneous than the $\mathrm{EPS}^{+}$cheese. This observation is in agreement with that of previous authors (Hassan and Awad, 2005; Rynne, 2006).
In both cheeses, the fat globules were also observed to be surrounded by cavities, probably as a result of the presence of expressible serum, as suggested by Hassan and Awad (2005). Also, bacterial colonies appeared to be concentrated in some areas rather than being evenly distributed throughout the matrix. This is thought to be attributable to the trapping of bacterial cells within the solid matrix as the gel is formed, thus immobilizing the cells as they grow into colonies (Hannon et al., 2006b).

\section{Texture Analysis}

Figure 4 shows the texture parameters (hardness, springiness, chewiness, fracture stress, adhesiveness, fracture strain, and cohesiveness) of the cheeses over 
ripening. In agreement with previous studies (Awad et al., 2005b; Dabour et al., 2006), the magnitude of most texture parameters decreased significantly $(P<0.001)$ over ripening, an effect that may be attributed to reduction of intact casein content, owing to its hydrolysis by the proteolytic activity of the residual chymosin and starter culture enzymes (Guinee, 2003; Gunasekaran and Mehmet, 2004). According to O'Mahony et al. (2005), the initial softening of Cheddar cheese texture that occurs during the early stages of ripening (initial 2 wk) is highly correlated with the transfer of caseinbound calcium phosphate to the aqueous phase of the cheese concentration of insoluble calcium. After this time, textural changes become more gradual as textural changes are attributed more to the rate of proteolysis and increase in $\mathrm{pH}$ (Gunasekaran and Mehmet, 2004).

Hardness (Figure 4A) was significantly $(P<0.05)$ lower in the $\mathrm{EPS}^{+}$cheese compared with the $\mathrm{EPS}^{-}$ cheese and decreased significantly $(P<0.001)$ throughout ripening in agreement with previous studies (Awad et al., 2005b; Dabour et al., 2006). This coincides with the lower intact casein content of the $\mathrm{EPS}^{+}$cheese, as a consequence of its higher levels of moisture content and proteolysis. Cheddar cheese is a viscoelastic solid in which the caseins form a protein network that entraps fat and moisture. By reducing the fat content, the microstructure of low-fat Cheddar cheese has a more compact protein matrix with less open spaces, which would otherwise have been occupied by the fat globules (Bryant et al., 1995). This correlated with the microstructure of the cheeses as shown in Figure 4, where a more dense and compact matrix was observed in the $\mathrm{EPS}^{-}$cheese compared with a more open, porous structure that retained moisture in the $\mathrm{EPS}^{+}$cheese. The increase in moisture was considered to reduce the texture profile analysis hardness. At the same time, the presence of the EPS within the cheese matrix may also have helped to reduce the hardness by filling voids in the matrix and by interacting with the proteins (AyalaHernandez et al., 2008). The level of hardness detected in the $\mathrm{EPS}^{+}$cheese is therefore more similar to that of full-fat Cheddar (Guinee et al., 2000).

Reduced-fat Cheddar cheese is known to possess more springiness because fewer fat globules are present and hence more casein is deformed per unit volume. This causes a resistance to deformation and the cheese fractures less easily (Gunasekaran and Mehmet, 2004). The $\mathrm{EPS}^{+}$cheese had a significantly lower $(P<0.001)$ level of springiness than the $\mathrm{EPS}^{-}$cheese, an effect that may be attributed to the lower content of intact casein and higher moisture content. Moreover, the presence of the EPS in the cheese matrix (Figure 3) may also be a mitigating factor.
Fracture stress (Figure 4C), but not fracture strain (Figure 4D), was significantly lower $(P<0.001)$ in the $\mathrm{EPS}^{+}$cheese. The lower fracture stress is attributable to the higher moisture, higher primary proteolysis, and lower $\mathrm{pH}$ detected in the $\mathrm{EPS}^{+}$cheese. This observation is consistent with previous studies (Dabour et al., 2006; Rynne, 2006).

Chewiness (Figure 4E) was significantly $(P<0.05)$ lower in the $\mathrm{EPS}^{+}$cheese. Cheese hardness correlated positively with chewiness $(\mathrm{r}=0.94)$, as previously observed (Beal and Mittal, 2000). Hence, in agreement with Awad et al. (2005b), the EPS ${ }^{-}$cheese was harder and therefore chewier than the $\mathrm{EPS}^{+}$cheese.

Adhesiveness (Figure 4F) significantly increased $(P$ $<0.001$ ) during ripening for the $\mathrm{EPS}^{+}$cheese, although the EPS $^{-}$cheese did not vary significantly with ripening time. Reduced-fat Cheddar cheeses are less adhesive than their full-fat counterparts (Bryant et al., 1995) because adhesiveness of Cheddar cheese decreases with the fat content. In agreement with previous studies (Awad et al., 2005b), adhesiveness was significantly ( $P$ $<0.001)$ higher in the $\mathrm{EPS}^{+}$cheese, which may suggest an increase in the viscosity of the aqueous phase as a result of the presence of EPS. Adhesiveness implies a decrease in elasticity and an increase in water-protein matrix interaction. Since the EPS is responsible for the greater water retention in the cheese (probably through hydrogen binding), there is an increase of water-protein matrix interaction, and hence, adhesiveness. Both cheeses showed little adhesiveness during the first month of ripening, but the $\mathrm{EPS}^{+}$cheese became more adhesive compared with the $\mathrm{EPS}^{-}$cheese from 2 mo of ripening. Moreover, adhesiveness also increases because of the ability of proteins to interact with water (Pastorino et al., 2003), which increases as a consequence of the hydrolysis of proteins during ripening. Hence, the adhesiveness was higher in the $\mathrm{EPS}^{+}$samples, which had higher levels of primary proteolysis throughout ripening.

The evolution of cohesiveness over ripening is shown in Figure 4G. According to Bryant et al. (1995), reduced-fat cheeses are usually more cohesive than fullfat cheeses. However, Dabour et al. (2006) reported a ratio of approximately 0.27 for full-fat Cheddar cheese and approximately 0.23 for reduced-fat Cheddar cheese (regardless of the presence of an EPS). In agreement with the latter authors, both of the cheeses in this study had a cohesiveness ratio of approximately 0.23 (Figure 4G). Because no significant differences were detected in the cohesiveness between the 2 cheeses, this suggests that the presence of the EPS and the increase in moisture has little effect on the cohesiveness of the cheeses. 
A

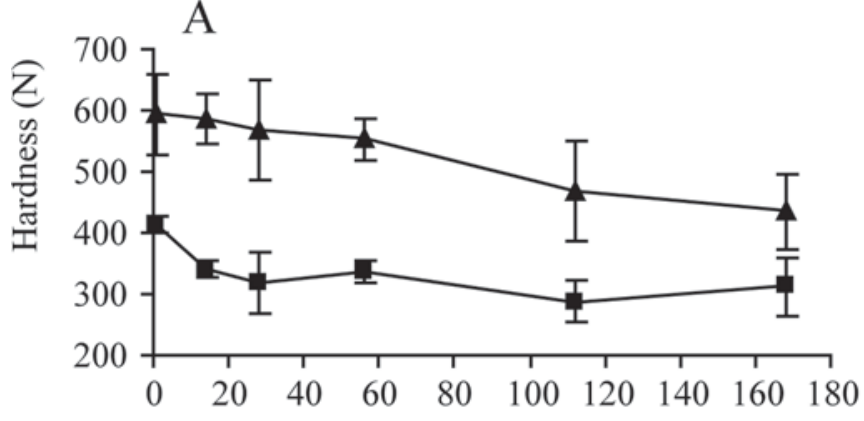

$\mathrm{C}$

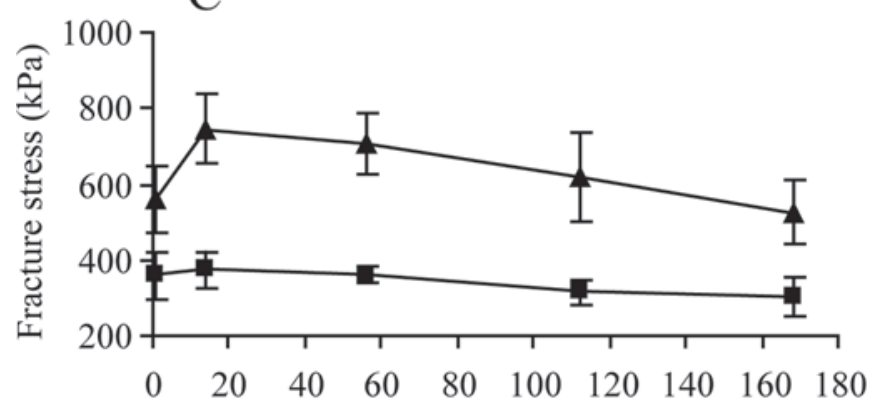

E
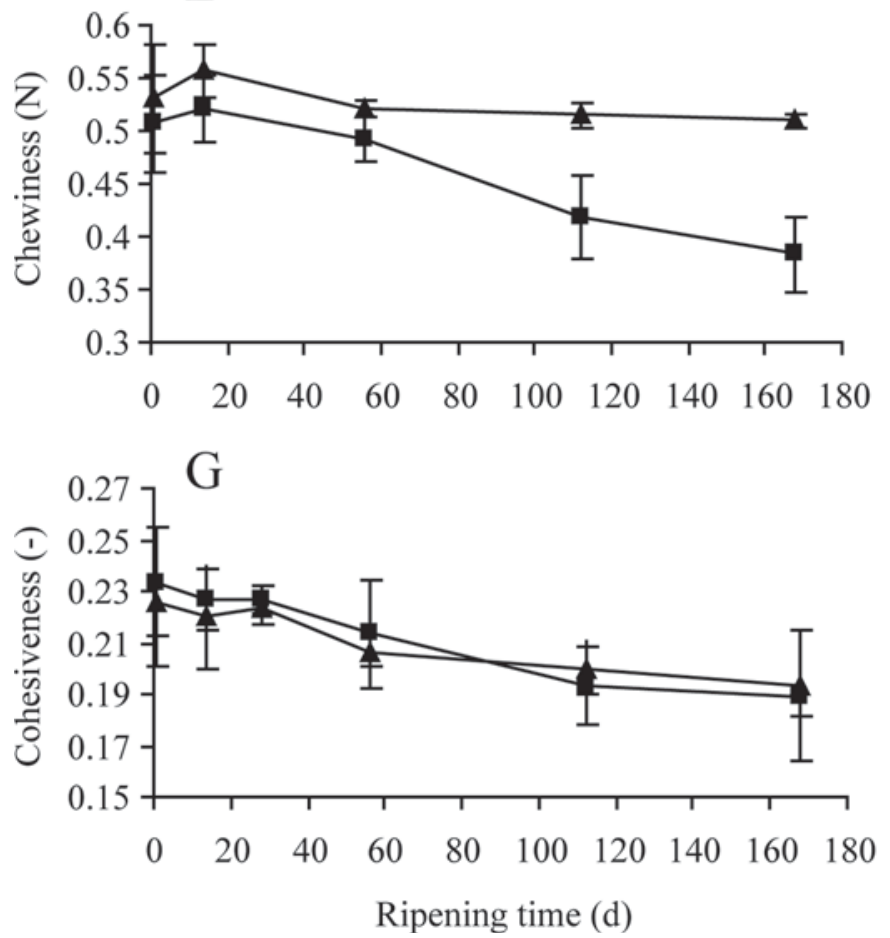

B
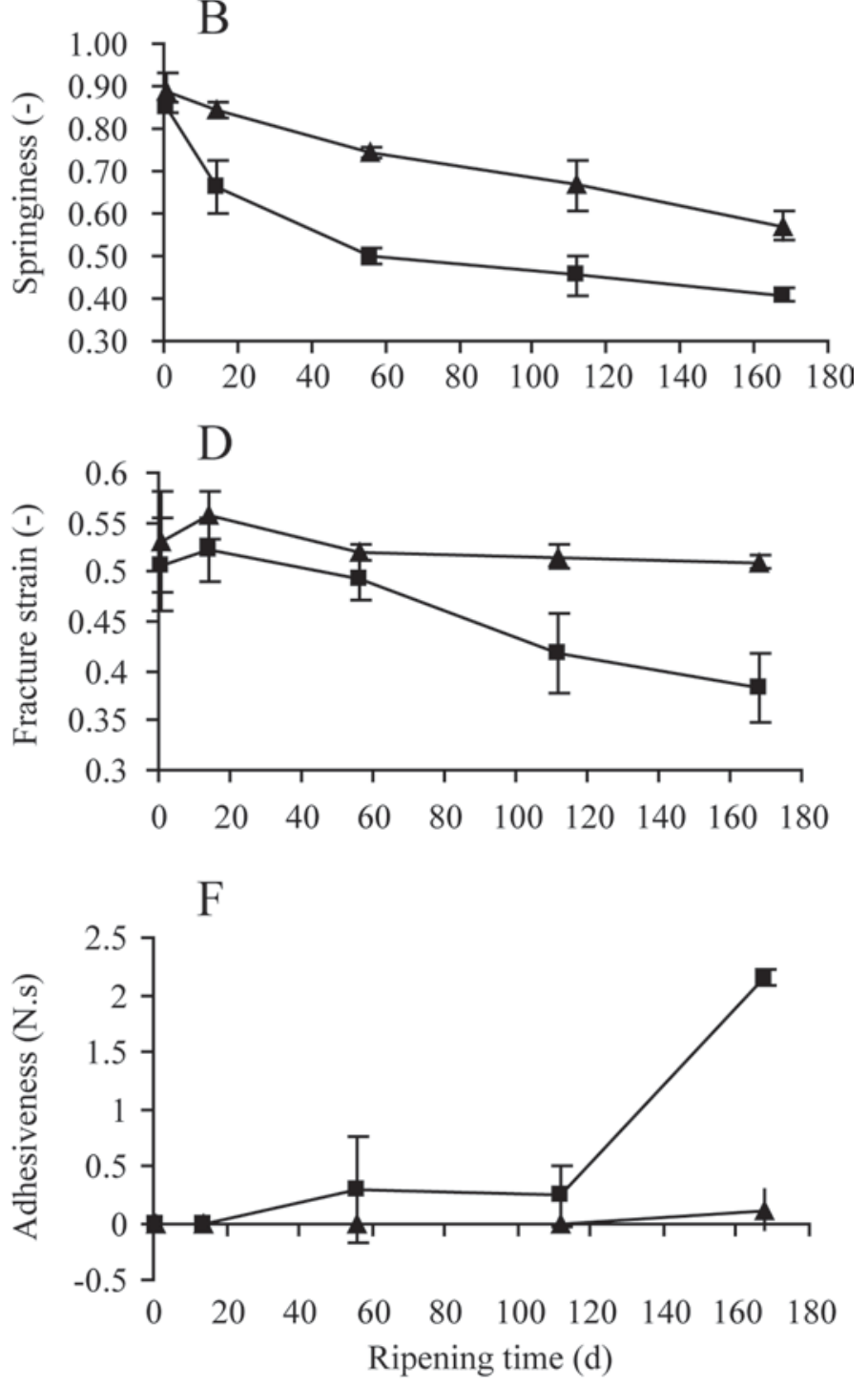

Figure 4. Evolution of texture parameters over ripening of half-fat Cheddar cheeses manufactured with exopolysaccharide-producing ( $\mathbf{\square})$ and non-exopolysaccharide-producing $(\mathbf{\Lambda})$ starters.

Figure 5 shows the texture map for both cheeses throughout ripening, plotted as described by Hammann and MacDonald (1992) and Lanier (1998). Both cheeses appeared on the left side of the plot and were described as not being overly rubbery or firm. The $\mathrm{EPS}^{+}$cheese was described to be mushy, soft, and short and the EPS $^{-}$cheese was described to be brittle. However, both cheeses became less brittle and more mushy as ripening 


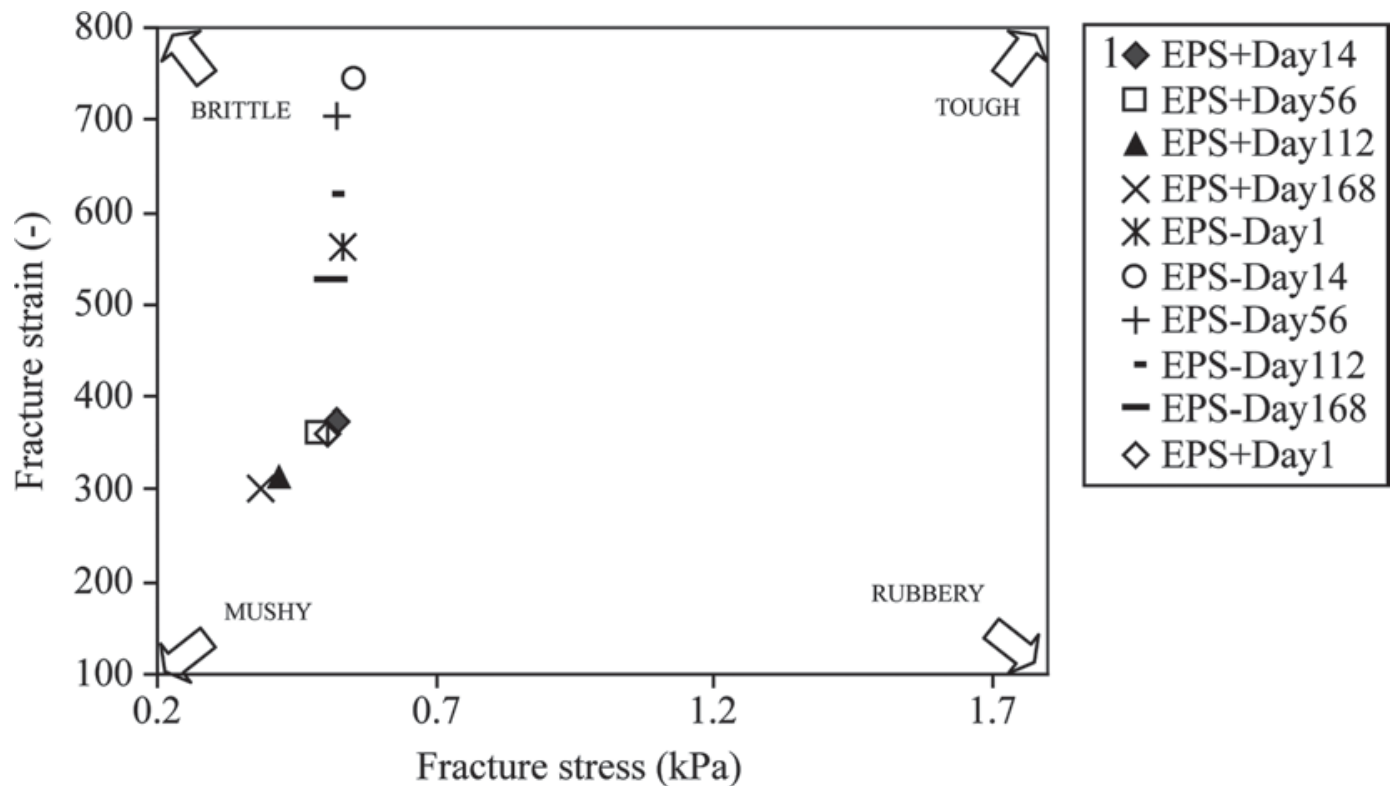

Figure 5. Texture map of half-fat Cheddar cheeses as described by Hammann and MacDonald (1992) and Lanier (1998). Arrows indicate increase in that textural attribute. EPS $^{+}=$cheese manufactured with a starter producing an exopolysaccharide $(\mathrm{EPS})$; EPS ${ }^{-}=$cheese manu- $^{-}$ factured with a starter not producing an EPS, followed by the ripening time at which they were analyzed.

progressed. Description of these terms can be found in Van Vliet (1991).

\section{Physical Characteristics of the Heated Cheese}

The changes in the heat-induced flowability of the cheeses during ripening are shown in Figure 6. Consistent with previous studies on reduced-fat Cheddar cheese (Awad et al., 2005b; Agrawal and Hassan, 2008), flowability significantly $(P<0.001)$ increased with ripening time as measured by 2 different methods (OlsonPrice and Schreiber). The levels of flowability in the $\mathrm{EPS}^{+}$cheese were similar to those reported for full-fat Cheddar cheese (Guinee et al., 2000).

The flow of the $\mathrm{EPS}^{+}$cheese was significantly higher than that of the $\mathrm{EPS}^{-}$cheese at all ripening times. Similar results were observed by others for reducedfat Cheddar cheese (Awad et al., 2005b; Agrawal and Hassan, 2008) and Mozzarella (McMahon et al., 1999) and have been attributed to the higher MNFS in the $\mathrm{EPS}^{+}$cheeses. Moreover, the higher flowability of the $\mathrm{EPS}^{+}$cheese may be associated with the lower content of intact casein, the numerically lower calcium:protein ratio, and the presence of the EPS within the moisture of the cheese, which may have limited the degree of casein fusion and matrix contraction post rennet gelation. Indeed, as discussed, the protein matrix of the $\mathrm{EPS}^{+}$cheese was more porous than that of the EPS cheese (Figure 3). Apparent viscosity and elastic shear modulus (at 40,60 , and $90^{\circ} \mathrm{C}$ ) at 6 mo of ripening were not significantly different between the 2 cheeses (data not shown).

\section{Water Activity and Dynamic Water Vapor Sorption-Desorption in the Cheese}

The $\mathrm{a}_{\mathrm{w}}$ was significantly $(P<0.001)$ higher in the $\mathrm{EPS}^{+}$cheese throughout ripening but did not significantly vary in either cheese over ripening (data not shown). The $\mathrm{a}_{\mathrm{w}}$ for the $\mathrm{EPS}^{-}$cheese $(0.955 \pm 0.0024$ at d 14) was similar to that reported previously for Cheddar cheese (Guinee and Fox, 2004). The higher $\mathrm{a}_{\mathrm{w}}$ in the $\mathrm{EPS}^{+}$cheese $(0.966 \pm 0.0014$ at $\mathrm{d} 14)$ suggests that the increased moisture attributable to the presence of the EPS is in the form of free water and may be trapped or weakly bound within the protein matrix as suggested by Hassan (2008). Figure 7 shows the isotherms obtained for both cheeses; the higher moisture loss from the $\mathrm{EPS}^{+}$cheese on decreasing the RH from 90 to $0 \%$ confirms the higher $\mathrm{a}_{\mathrm{w}}$ detected in the $\mathrm{EPS}^{+}$cheese. Despite its higher water content, the $\mathrm{EPS}^{+}$cheese lost significantly $(P<0.001)$ greater $(8 \%$ more $)$ weight of water (per gram of cheese) during desorption relative to the initial moisture content of the cheese and had significantly $(P<0.001)$ lower $(10 \%$ less $)$ levels of residual water (per gram cheese) at the end. This also suggests that the extra water present in the $\mathrm{EPS}^{+}$cheese may just be trapped within the matrix or weakly bound (through hydrogen bonding of the EPS) and, hence, is more easily released. This hypothesis correlates well 
with the microstructural images obtained on the cryoSEM (Figure 3) because the complex EPS network observed would have the capacity to trap more moisture.

\section{Cheese Microbiology and Lysis}

Figure 8 shows the counts of starters (L. lactis ssp. cremoris DPC 6532 or 6533) and NSLAB throughout the $168 \mathrm{~d}$ of ripening. On $\mathrm{d} 1$, the mean starter population was in the range of $10^{8}$ to $10^{9} \mathrm{cfu} / \mathrm{g}$ of cheese, typical for starter counts previously reported in halffat Cheddar cheese (Fenelon et al., 2002; Rynne et al., 2007b). By 4 mo of ripening, starter populations had decreased significantly to approximately $10^{6} \mathrm{cfu} / \mathrm{g}$ of cheese. This decrease of 2 to 3 log suggests that these lactoccocal strains (both DPC 6532 and 6533) are autolytic (O'Donovan et al., 1996; Sheehan et al., 2006). No significant differences were detected in the starter counts between the $\mathrm{EPS}^{+}$and $\mathrm{EPS}^{-}$cheeses.

The levels of NSLAB increased significantly throughout ripening, from $10^{1}$ to $10^{2} \mathrm{cfu} / \mathrm{g}$ of cheese at $\mathrm{d} 1$ to $10^{6}$ to $10^{7} \mathrm{cfu} / \mathrm{g}$ of cheese after $168 \mathrm{~d}$, following a similar trend as previously reported for half-fat Cheddar cheeses (Fenelon et al., 2002; Rynne, 2006). Despite the $\mathrm{EPS}^{+}$cheeses having a higher moisture content and consequently higher $\mathrm{a}_{\mathrm{w}}$, no significant differences were
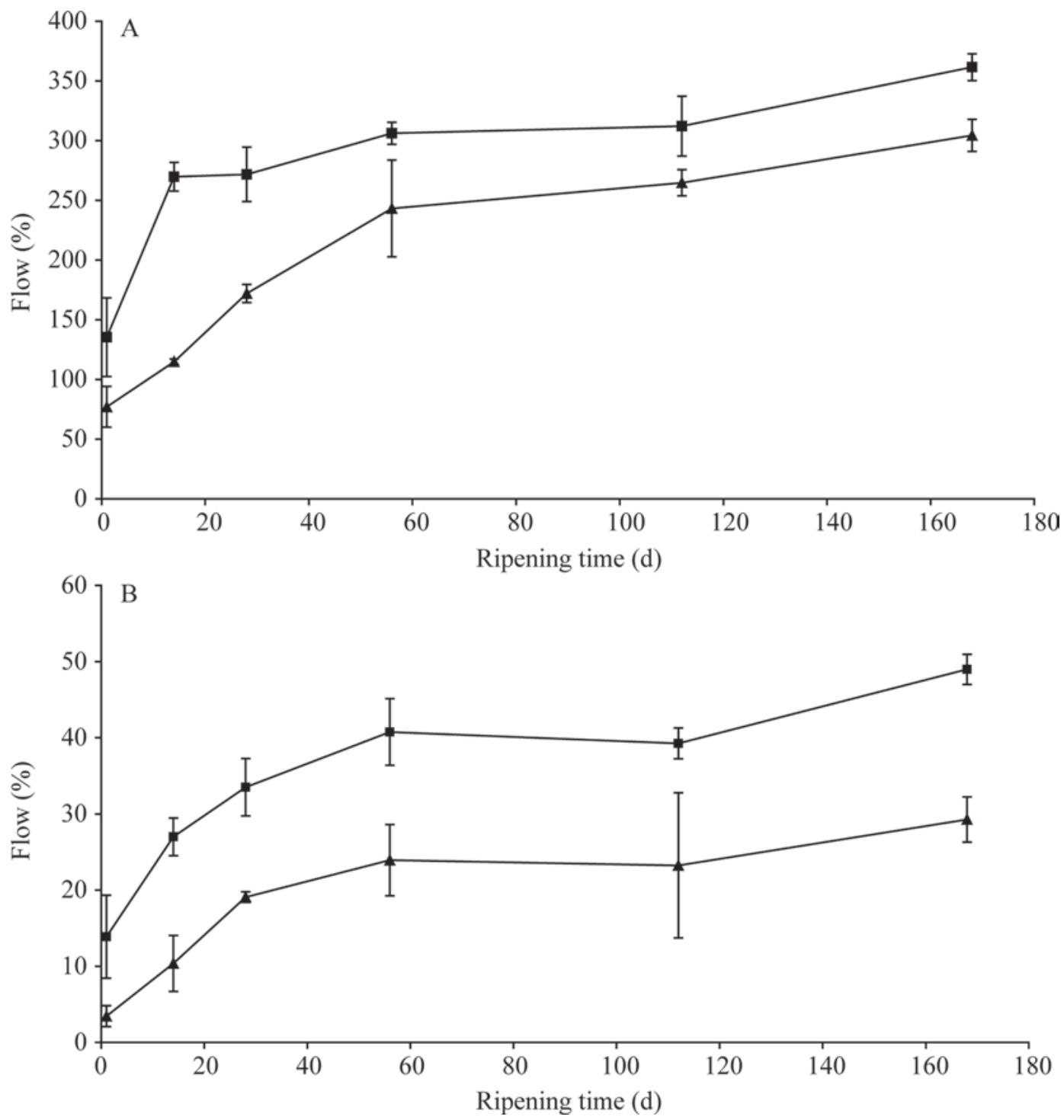

Figure 6. Evolution of the flowability as measured by (A) the Olson-Price method and (B) the Schreiber method during ripening of half-fat Cheddar cheeses manufactured with exopolysaccharide-producing $(\boldsymbol{\square})$ and non-exopolysaccharide-producing $(\boldsymbol{\Lambda})$ starters. 


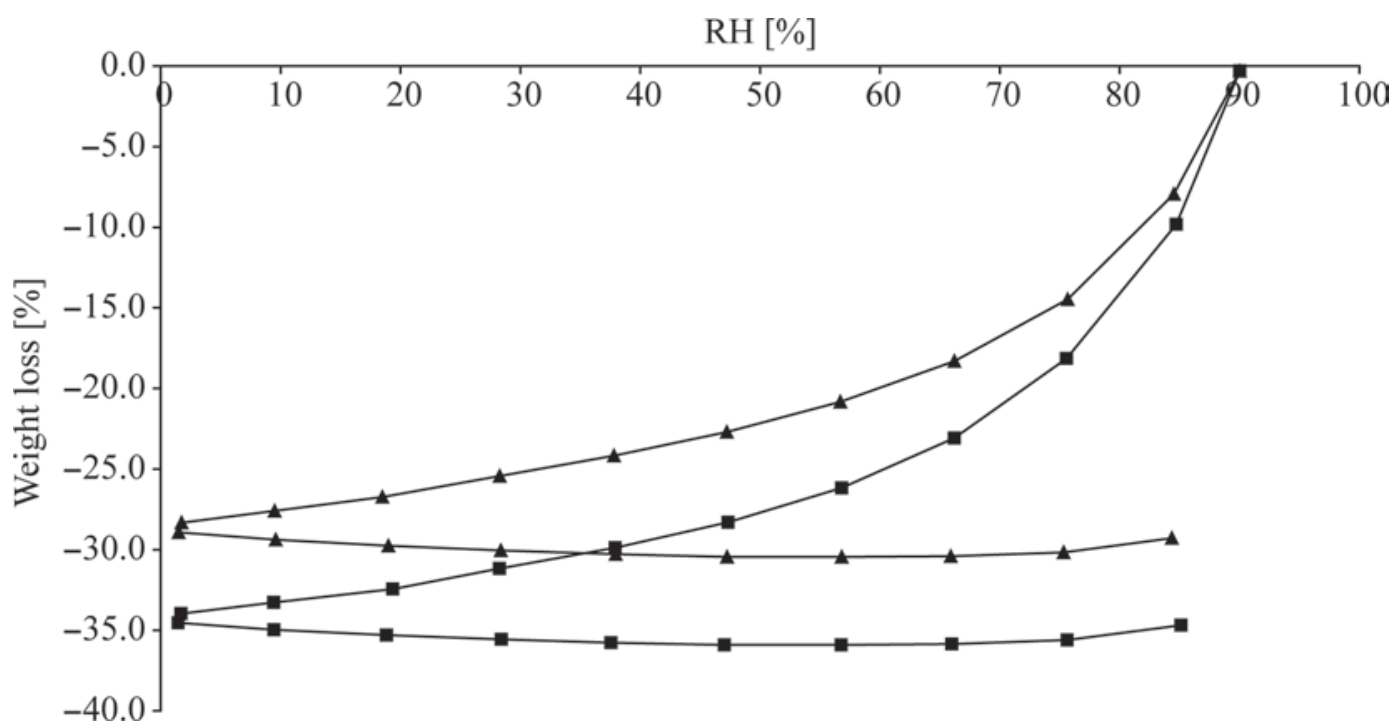

Figure 7. Moisture equilibrium isotherms for half-fat Cheddar cheeses manufactured with exopolysaccharide-producing ( $\mathbf{\square})$ and non-exopolysaccharide-producing $(\mathbf{\Lambda})$ starters at 6 mo of ripening. $\mathrm{RH}=$ relative humidity.

observed between the 2 cheeses for the levels of NSLAB. This is consistent with previous studies on EPS cultures in half-fat Cheddar cheese (Rynne, 2006).

No significant differences were detected between the levels of LDH activity in the cheeses $\left(\mathrm{EPS}^{+}\right.$and $\left.\mathrm{EPS}^{-}\right)$. The autolytic pattern for both strains is very similar, increasing significantly $(P<0.001)$ over time, and is coherent with the reduction of viable numbers as detected by plate counts. This suggests that the presence of an EPS has little effect on the induction or inhibition of lysis.

\section{Flavor Analysis}

$\boldsymbol{F F A}$. The levels of total FFA at 6 mo of ripening did not differ significantly between the cheeses. The levels detected were $468 \mathrm{mg} / \mathrm{kg}$ of cheese for the EPS ${ }^{+}$ cheese and $456 \mathrm{mg} / \mathrm{kg}$ for the $\mathrm{EPS}^{-}$cheese. Because the

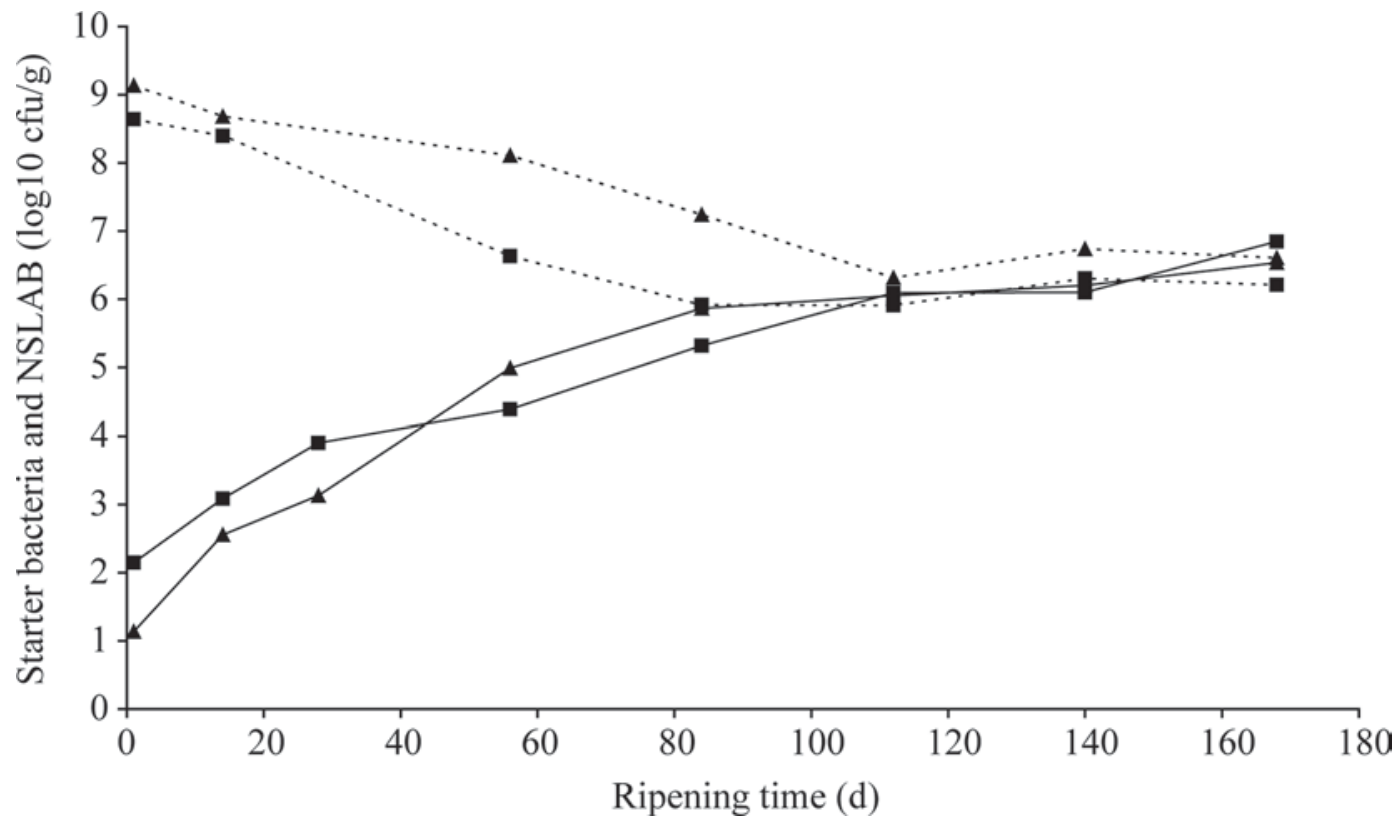

Figure 8. Evolution of mean counts of starter (dotted lines) and nonstarter lactic acid bacteria (NSLAB; continuous lines) for half-fat Cheddar cheeses manufactured with exopolysaccharide-producing (ם) and non-exopolysaccharide-producing $(\mathbf{\Delta})$ starters. 
Table 3. Trained panel descriptive flavor and texture profiles of halffat Cheddar cheeses made with $\mathrm{EPS}^{+}$and $\mathrm{EPS}^{-}$starters $^{1}$ at 6 mo of ripening

\begin{tabular}{lcc}
\hline Item & $\mathrm{EPS}^{+}$ & $\mathrm{EPS}^{-}$ \\
\hline Flavor attribute & & \\
Cooked & $2.6^{\mathrm{a}}$ & $2.6^{\mathrm{a}}$ \\
Whey & $2.0^{\mathrm{a}}$ & $1.9^{\mathrm{a}}$ \\
Milkfat & $1.7^{\mathrm{a}}$ & $1.4^{\mathrm{b}}$ \\
Sulfur & $1.7^{\mathrm{b}}$ & $2.2^{\mathrm{a}}$ \\
Brothy & $2.6^{\mathrm{b}}$ & $2.9^{\mathrm{a}}$ \\
Nutty & $\mathrm{ND}^{3}$ & $1.0^{\mathrm{a}}$ \\
Cowy & $1.7^{\mathrm{a}}$ & $1.5^{\mathrm{a}}$ \\
Mothball & $1.1^{\mathrm{b}}$ & $1.5^{\mathrm{a}}$ \\
Sweet & $2.1^{\mathrm{a}}$ & $2.0^{\mathrm{a}}$ \\
Sour & $3.2^{\mathrm{a}}$ & $2.9^{\mathrm{b}}$ \\
Bitter & $0.6^{\mathrm{b}}$ & $1.0^{\mathrm{a}}$ \\
Salty & $3.2^{\mathrm{a}}$ & $3.2^{\mathrm{a}}$ \\
Umami & $1.9^{\mathrm{a}}$ & $1.8^{\mathrm{a}}$ \\
Texture attribute & & \\
Hfirmness & $12.8^{\mathrm{b}}$ & $13.7^{\mathrm{a}}$ \\
Hspringiness & $12.6^{\mathrm{a}}$ & $12.9^{\mathrm{a}}$ \\
Hrate of recovery & $10.0^{\mathrm{b}}$ & $13.0^{\mathrm{a}}$ \\
Firmness & $9.9^{\mathrm{b}}$ & $11.6^{\mathrm{a}}$ \\
Fracturability & $8.1^{\mathrm{a}}$ & $8.4^{\mathrm{a}}$ \\
Degree of breakdown & $4.2^{\mathrm{a}}$ & $2.2^{\mathrm{b}}$ \\
Cohesiveness & $4.9^{\mathrm{a}}$ & $4.1^{\mathrm{b}}$ \\
Adhesiveness & $4.8^{\mathrm{a}}$ & $4.2^{\mathrm{b}}$ \\
Smoothness of mass & $4.9^{\mathrm{a}}$ & $4.2^{\mathrm{b}}$ \\
Smoothness of mouthcoating & $6.6^{\mathrm{a}}$ & $3.6^{\mathrm{b}}$ \\
\hline
\end{tabular}

${ }^{a, b}$ Values within a column not sharing a common superscript differ significantly $(P<0.05)$.

${ }^{1} \mathrm{EPS}^{+}=$cheese manufactured with a starter producing an exopolysaccharide (EPS); EPS $^{-}=$cheese manufactured with a starter not producing an EPS.

${ }^{2}$ Cheeses were scored on a 15-point universal intensity scale (Spectrum method) (Meilgaard et al., 1999). A description of the flavor attributes can be found in Drake et al. (2001), and a description of the texture sensory language can be found in Brown et al. (2003).

${ }^{3} \mathrm{ND}=$ not detected.

${ }^{4}$ Hfirmness = hand firmness; Hspringiness = hand springiness; Hrate of recovery $=$ hand rate of recovery.

cheeses were made from the same milk, no significant differences were detected for total or individual FFA between the 2 cheeses as expected. Lipolysis in Cheddar cheese is known to be limited (200-1,000 mg/kg of cheese) and FFA originate mainly from the lipolysis of milk fat rather than from the metabolism of carbohydrates and AA by bacteria (Aston and Dulley, 1982; McSweeney, 2004).

Volatile Analyses. No significant differences were detected in the volatile profile between the 2 cheeses, suggesting that the presence of an EPS has no effect on the production of volatile compounds (data not shown). Many volatile chemical compounds are implicated in cheese flavor (Urbach, 1997). These compounds originate from the action of cheese microorganisms and their enzymes on the lactose, lipids, and proteins of cheese curd (Rehman et al., 2000). Because the milk used in this study was treated in the same way, and because the levels of NSLAB as well as the enzymatic potential of the starter strains in the cheeses were very similar, it was not surprising that few differences were detected between the 2 cheeses in terms of their volatile profiles.

Sensory Analysis. Table 3 shows the flavor and texture scores of the cheeses as determined by quantitative descriptive sensory analysis. Significant flavor $(P$ $<0.05)$ differences between the cheeses were detected for milkfat, sulfur, brothy, mothball, sour, and bitter. Bitterness is known to be a common defect in cheeses containing EPS because of the increased moisture and higher residual chymosin activity (Awad et al., 2005a; Agrawal and Hassan, 2007). However, in this study, the $\mathrm{EPS}^{+}$cheese appeared to be significantly less bitter than the EPS ${ }^{-}$cheese despite the $\mathrm{EPS}^{+}$cheese having higher moisture, higher levels of primary proteolysis, and theoretically higher levels of residual chymosin. Also, no differences were observed in the amount of bitter peptides in the reverse phase-HPLC chromatograms. The bitterness that other authors detected could be attributed to the enzymatic potential of the different strains and not to the presence of the EPS itself.

The texture profile obtained using a trained sensory panel correlated well with textural measurements obtained using the texture profile analyzer. Firmness, hand firmness, and hand rate of recovery correlated with texture profile analysis and were significantly $(P<$ 0.05) higher in the EPS ${ }^{-}$cheese. Also, the EPS ${ }^{+}$cheese was found to be significantly $(P<0.05)$ more adhesive, again correlating well with the texture profile analyzer measurements. However, some differences between the texture profile analyzer profiles and the sensory panel profiles were found: fracturability or hand springiness were not significantly different and cohesiveness significantly different $(P<0.05)$ in the $\mathrm{EPS}^{+}$cheese according to the sensory panel but not according to the texture profile analyses.

\section{CONCLUSIONS}

By using isogenic starter strains differing only in their ability to produce EPS, this study provided for the first time a clear understanding of the direct role of an EPS produced by the starter in Cheddar cheese minimizing the effects of starter strain dependency and different enzymatic potentials. No effect was observed on the renneting properties, whereas a significant increase in the yield $(\sim 8 \%)$ was detected and attributed to the increase in the moisture content. As suggested by the higher $\mathrm{a}_{\mathrm{w}}$ and the sorption-desorption assay, this extra moisture is thought to be in the form of free water and not strongly bound as some authors previously suggested. Cryo-SEM micrographs revealed a highly porous structure containing numerous cavities capable 
of trapping the extra moisture. The presence of the EPS did not affect lysis of either starter strain or the development of the NSLAB flora. In the $\mathrm{EPS}^{+}$cheese primary proteolysis was higher throughout ripening but secondary proteolysis was lower up to 2 mo and higher after 3 mo of ripening. Inclusion of the EPS resulted in texture and melting properties similar to levels reported for full-fat Cheddar, an effect attributed to the higher MNSF, diluted intact casein, and higher levels of primary proteolysis. Ultimately, inclusion of the EPS had little effect on the final flavor of the cheeses. Further studies are ongoing to establish the nature of the EPS and its mechanism in altering the properties of cheese.

\section{ACKNOWLEDGMENTS}

The authors acknowledge Paula Reid (Ashtown Food Research Centre, Dublin, Ireland) for her assistance on the statistical analysis of the data and Raluca Alexa (Moorepark Food Research Centre, Fermoy, Ireland) for her technical assistance on the viscosity measurements. Funding for this research was provided under the Food Institutional Research Measure (FIRM) by the Irish Department of Agriculture Fisheries and Food as part of the National Development Plan $(04 / \mathrm{R} \& \mathrm{D} /$ $\mathrm{TD} / 309)$.

\section{REFERENCES}

Agrawal, P., and A. N. Hassan. 2007. Ultrafiltered milk reduces bitterness in reduced fat Cheddar cheese made with an exopolysaccharideproducing culture. J. Dairy Sci. 90:3110-3117.

Agrawal, P., and A. N. Hassan. 2008. Characteristics of reduced fat Cheddar cheese made from ultrafiltered milk with an exopolysaccharide-producing culture. J. Dairy Res. 75:182-188.

Aston, J., and J. Dulley. 1982. Cheddar cheese flavor. Aust. J. Dairy Technol. 37:59-64.

Awad, S., A. N. Hassan, and F. Halaweish. 2005a. Application of exopolysaccharide-producing cultures in reduced-fat Cheddar cheese: Composition and proteolysis. J. Dairy Sci. 88:4195-4203.

Awad, S., A. N. Hassan, and K. Muthukumarappan. 2005b. Application of exopolysaccharide-producing cultures in reduced-fat Cheddar cheese: Texture and melting properties. J. Dairy Sci. 88:42044213.

Ayala-Hernandez, I., H. D. Goff, and M. Corredig. 2008. Interactions between milk proteins and exopolysaccharides produced by Lactococcus lactis observed by scanning electron microscopy. J. Dairy Sci. 91:2583-2590.

Beal, P., and G. S. Mittal. 2000. Vibration and compression responses of Cheddar cheese at different fat content and age. Milchwissenschaft $55: 139-142$.

Bourne, M. C. 1978. Texture profile analysis. Food Technol. 32:62-66, 72 .

British Standards Institution. 1976. Chemical analysis of cheese. Part 5: Determination of $\mathrm{pH}$ value. British Standard 770. British Standards Institution, London, UK.

Brown, J. A., E. A. Foegeding, C. R. Daubert, and M. A. Drake. 2003. Changes in rheological and sensorial properties of young cheeses as related to maturation. J. Dairy Sci. 86:3054-3067.

Bryant, A., Z. Ustunol, and J. Steffe. 1995. Texture of Cheddar cheese as influenced by fat reduction. J. Food Sci. 60:1216-1219.
Carunchia-Whetstine, M., Y. Karagul-Yuceer, Y. K. Avsar, and M. A. Drake. 2003. Aroma-active components of fresh goat cheeses. J. Food Sci. 68:2441-2447.

Cogan, T. M., M. O'Dowd, and D. Mellerick. 1981. Effects of pH and sugar on acetoin production from citrate by Leuconostoc lactis. Appl. Environ. Microbiol. 41:1-8.

Dabour, N., E. Kheadr, N. Benhamou, I. Fliss, and G. LaPointe. 2006. Improvement of texture and structure of reduced-fat Cheddar cheese by exopolysaccharide-producing lactococci. J. Dairy Sci. $89: 95-110$

Dabour, N., E. E. Kheadr, I. Fliss, and G. LaPointe. 2005. Impact of ropy and capsular exopolysaccharide-producing strains of Lactococcus lactis ssp. cremoris on reduced-fat Cheddar cheese production and whey composition. Int. Dairy J. 15:459-471.

De Jong, C., and T. H. Badings. 1990. Determination of free fatty acids in milk and cheese procedures for extraction, clean up and capillary gas chromatographic analysis. J. High Resolut. Chromatogr. 13:94-98.

Drake, M. A., and G. V. Civille. 2003. Flavor lexicons. Comp. Rev. Food Sci. 2:33-40.

Drake, M. A., S. C. McIngvale, K. R. Cadwallader, and G. V. Civille. 2001. Development of a descriptive sensory language for Cheddar cheese. J. Food Sci. 66:1422-1427.

Drake, M. A., M. D. Yates, P. D. Gerard, C. M. Delahunty, E. M. Sheehan, R. P. Turnbull, and T. M. Dodds. 2005. Comparison of differences between lexicons for descriptive analysis of Cheddar cheese flavor in Ireland, New Zealand, and the United States of America. Int. Dairy J. 15:473-483.

Fenelon, M. A., T. P. Beresford, and T. P. Guinee. 2002. Comparison of different bacterial culture systems for the production of reducedfat Cheddar cheese. Int. J. Dairy Technol. 55:194-203.

Fenelon, M. A., and T. P. Guinee. 1999. The effect of milk fat on cheddar cheese yield and its prediction, using modifications of the Van Slyke cheese yield formula. J. Dairy Sci. 82:2287-2299.

Fenelon, M. A., P. O'Connor, and T. P. Guinee. 2000. The effect of fat content on the microbiology and proteolysis in Cheddar cheese during ripening. J. Dairy Sci. 83:2173-2183.

Fenelon, M. A., M. P. Ryan, M. C. Rea, T. P. Guinee, R. P. Ross, C. Hill, and D. Harrington. 1999. Elevated temperature ripening of reduced fat Cheddar made with or without Lacticin 3147-producing starter culture. J. Dairy Sci. 82:10-22.

Guinee, T., and P. L. H. McSweeney. 2006. Significance of milk fat in cheese. Pages 377-440 in Advanced Dairy Chemistry. Vol. 2: Lipids. 3rd ed. P. F. Fox and P. L. H McSweeney, ed. Springer, New York, NY.

Guinee, T. P. 2003. Role of protein in cheese and cheese products. Pages 1083-1174 in Advanced Dairy Chemistry. Vol. 1: Proteins. P. F. Fox and P. L. H. McSweeney, ed. Kluwer Academic/Plenum Press, New York, NY.

Guinee, T. P., M. Auty, and C. Mullins. 1999. Observations on the microstructure and "heat induced" changes in the viscoelasticity of commercial cheeses. Aust. J. Dairy Technol. 54:84-89.

Guinee, T. P., M. A. E. Auty, and M. A. Fenelon. 2000. The effect of fat content on the rheology, microstructure and heat-induced functional characteristics of Cheddar cheese. Int. Dairy J. 10:277288.

Guinee, T. P., E. P. Feeney, M. A. E. Auty, and P. F. Fox. 2002. Effect of $\mathrm{pH}$ and calcium concentration on some textural and functional properties of Mozzarella cheese. J. Dairy Sci. 85:1655-1669.

Guinee, T. P., and P. F. Fox. 2004. Salt in cheese: Physical, chemical and biological aspects. Pages 207-259 in Cheese: Chemistry, Physics and Microbiology. General Aspects. Vol. 1. 3rd ed. P. F. Fox, P. L. H. McSweeney, T. M. Cogan, and T. P. Guinee, ed. Academic Press, London, UK.

Guinee, T. P., D. J. O'Callaghan, P. D. Pudja, and N. O'Brien. 1996. Rennet coagulation properties of retentates obtained by ultrafiltration of skim milks heated to different temperatures. Int. Dairy J. 6:581-596.

Guinee, T. P., B. T. O'Kennedy, and P. M. Kelly. 2006. Effect of milk protein standardization using different methods on the composition and yields of Cheddar cheese. J. Dairy Sci. 89:468-482. 
Gunasekaran, S., and M. A. Mehmet. 2004. Cheese texture. Pages 299-324 in Cheese Rheology and Texture. CRC Press LLC, Boca Raton, FL.

Hamann, D. D., and G. A. MacDonald. 1992. Rheology and texture properties of surimi and surimi-based foods. Pages $429-500$ in Surimi Technology. T. C. Lanier and C. M. Lee, ed. Marcel Dekker, New York, NY.

Hannon, J. A., S. M. Deutsch, M. N. Madec, J. Y. Gassi, M. P. ChapotChartier, and S. Lortal. 2006a. Lysis of starters in UF cheeses: Behaviour of mesophilic lactococci and thermophilic lactobacilli. Int. Dairy J. 16:324-334.

Hannon, J. A., C. Lopez, M. N. Madec, and S. Lortal. 2006b. Altering renneting $\mathrm{pH}$ changes microstructure, cell distribution, and lysis of Lactococcus lactis AM2 in cheese made from ultrafiltered milk. J. Dairy Sci. 89:812-823.

Hannon, J. A., M. G. Wilkinson, C. M. Delahunty, J. M. Wallace, P. A. Morrissey, and T. P. Beresford. 2003. Use of autolytic starter systems to accelerate the ripening of Cheddar cheese. Int. Dairy J. $13: 313-323$.

Hannon, J. A., M. G. Wilkinson, C. M. Delahunty, J. M. Wallace, P. A. Morrissey, and T. P. Beresford. 2005. Application of descriptive sensory analysis and key chemical indices to assess the impact of elevated ripening temperatures on the acceleration of Cheddar cheese ripening. Int. Dairy J. 15:263-273.

Hassan, A. N. 2008. ADSA Foundation Scholar Award: Possibilities and challenges of exopolysaccharide-producing lactic cultures in dairy foods. J. Dairy Sci. 91:1282-1298.

Hassan, A. N., and S. Awad. 2005. Application of exopolysaccharideproducing cultures in reduced-fat Cheddar cheese: Cryo-scanning electron microscopy observations. J. Dairy Sci. 88:4214-4220.

Hassan, A. N., S. Awad, and K. Muthukumarappan. 2005. Effects of exopolysaccharide-producing cultures on the viscoelastic properties of reduced-fat Cheddar cheese. J. Dairy Sci. 88:4221-4227.

Hassan, A. N., M. Corredig, J. F. Frank, and M. El Soda. 2004. Microstructure and rheology of an acid-coagulated cheese (Karish) made with an exopolysaccharide-producing Streptococcus thermophilus strain and its exopolysaccharide non-producing genetic variant. J. Dairy Res. 71:116-120.

Hassan, A. N., and J. F. Frank. 1997. Modification of microstructure and texture of rennet curd by using a capsule-forming non-ropy lactic culture. J. Dairy Res. 64:115-121.

Hickey, D. K., K. N. Kilcawley, T. P. Beresford, E. M. Sheehan, and M. G. Wilkinson. 2006. The influence of a seasonal milk supply on the biochemical and sensory properties of Cheddar cheese. Int. Dairy J. 16:679-690.

International Dairy Federation. 1964. Determination of the ash content of processed cheese products. Standard 27. International Dairy Federation, Brussels, Belgium.

International Dairy Federation. 1981. Cheese and processed cheese products-Determination of chloride content (potentiometer titration method). Standard 88A. International Dairy Federation, Brussels, Belgium.

International Dairy Federation. 1982. Cheese and processed cheese-Determination of the total solids content. Standard 4A. International Dairy Federation, Brussels, Belgium.

International Dairy Federation. 1984. Milk \& dried milk. Determination of calcium content, flame atomic absorption spectrometric method. Standard 154. International Dairy Federation, Brussels, Belgium.

International Dairy Federation. 1986. Cheese and processed cheese products-Determination of fat content (gravimetric method). Standard 5B. International Dairy Federation, Brussels, Belgium.

International Dairy Federation. 1993. Milk determination of nitrogen content. Standard 20B. International Dairy Federation, Brussels, Belgium.

International Dairy Federation. 2001. Determination of nitrogen content-Part 2: Block digestion method (macro method). IDF Standard 20-2. International Dairy Federation, Brussels, Belgium.

Jiménez-Guzmán, J., A. Flores-Nájera, A. E. Cruz-Guerrero, and M. García-Garibay. 2009. Use of an exopolysaccharide-producing strain of Streptococcus thermophilus in the manufacture of Mexican Panela cheese. LWT-Food Sci. Technol. 42:1508-1512.

Kuchroo, C. N., and P. F. Fox. 1982. Fractionation of the watersoluble nitrogen from Cheddar cheese: Chemical methods. Milchwissenschaft 37:651-653.

Lanier, T. C. 1998. Practical Applications of Fracture Data in Rheological Analysis of Foods. Theory and Practice. Short Course, May 20-22, 1998, North Carolina State University, Raleigh.

McMahon, D. J., R. L. Fife, and C. J. Oberg. 1999. Water partitioning in Mozzarella cheese and its relationship to cheese meltability. J. Dairy Sci. 82:1361-1369.

McSweeney, P. L. H. 2004. Biochemestry of cheese ripening. Pages 347-360 in Cheese: Chemistry, Physics and Microbiology. General Aspects. Vol. 1. 3rd ed. P. F. Fox, P. L. H. McSweeney, T. M. Cogan, and T. P. Guinee, ed. Academic Press, London, UK.

Meilgaard, M., G. Civille, and B. Carr. 1999. Descriptive analysis techniques. Pages 173-183 in Sensory Evaluation Techniques. M. Meilgaard, G. Civille, and B. Carr, ed. CRC Press, Boca Raton, FL.

Mistry, V. V. 2001. Low fat cheese technology. Int. Dairy J. 11:413422

Mounsey, J. S., C. E. Stathopoulos, S. Chockchaisawasdee, B. T. O'Kennedy, V. Gee, and J. Doyle. 2008. Effect of zinc fortification on rheological properties and microstructure of water-in-oil spreads containing K-carrageenan. Eur. Food Res. Technol. 227:675-681.

O'Callaghan, D. J., and T. P. Guinee. 1995. Comparison of mathematical models applied to the rennet coagulation of skim milks. J. Texture Stud. 26:607-633.

O'Donovan, C. M., M. G. Wilkinson, T. P. Guinee, and P. F. Fox. 1996. An investigation of the autolytic properties of three lactococcal strains during cheese ripening. Int. Dairy J. 6:1149-1165.

O'Mahony, J. A., J. A. Lucey, and P. L. H. McSweeney. 2005. Chymosin-mediated proteolysis, calcium solubilization, and texture development during the ripening of Cheddar cheese. J. Dairy Sci. 88:3101-3114.

Pastorino, A. J., C. L. Hansen, and D. J. McMahon. 2003. Effect of salt on structure-function relationships of cheese. J. Dairy Sci. 86:60-69.

Rehman, S.-U., J. M. Banks, E. Y. Brechany, D. D. Muir, P. L. H. McSweeney, and P. F. Fox. 2000. Influence of ripening temperature on the volatiles profile and flavor of Cheddar cheese made from raw or pasteurised milk. Int. Dairy J. 10:55-65.

Rogosa, M., J. A. Mitchell, and R. F. Wiseman. 1951. A selective medium for the isolation and enumeration of oral and fecal lactobacilli. J. Bacteriol. 62:132-133.

Rößle, C., M. A. E. Auty, N. Brunton, R. T. Gormley, and F. Butler. 2009. Evaluation of fresh-cut apple slices enriched with probiotic bacteria. Innovat. Food Sci. Emerg. Tech. 11:203-209.

Rynne, N. M. 2006. Effect of various factors on the composition, biochemical, functional and sensory properties of reduced-fat Cheddar cheese. PhD Thesis. Moorepark Food Research Centre and University College Cork, Ireland.

Rynne, N. M., T. P. Beresford, A. L. Kelly, and T. P. Guinee. 2004. Effect of milk pasteurization temperature and in situ whey protein denaturation on the composition, texture and heat-induced functionality of half-fat Cheddar cheese. Int. Dairy J. 14:9891001.

Rynne, N. M., T. P. Beresford, A. L. Kelly, and T. P. Guinee. 2007a. Effect of milk pasteurisation temperature on age-related changes in lactose metabolism, $\mathrm{pH}$ and the growth of non-starter lactic acid bacteria in half-fat Cheddar cheese. Food Chem. 100:375-382.

Rynne, N. M., T. P. Beresford, A. L. Kelly, M. H. Tunick, E. Malin, and T. P. Guinee. 2007b. Effect of exopolysaccharide-producing adjunct starter cultures on the manufacture, composition and yield of half-fat Cheddar cheese. Aust. J. Dairy Technol. 62:12-18.

Sallami, L., E. E. Kheadr, I. Fliss, and J. C. Vuillemard. 2004. Impact of autolytic, proteolytic, and nisin-producing cultures on biochemical and textural properties of Cheddar cheese. J. Dairy Sci. $87: 1585-1594$. 
Scott, R., R. K. Robinson, and R. A. Wilbey. 1998. Tests for acidity and chemical analysis in process control. Pages 85-86 in Cheesemaking Practice. 3rd ed. R. Scott, ed. Aspen Publishers, Gaithersburg, MD.

Sheehan, A., G. O' Cuinn, R. J. FitzGerald, and M. G. Wilkinson. 2006. Proteolytic enzyme activities in Cheddar cheese juice made using lactococcal starters of differing autolytic properties. J. Appl. Microbiol. 100:893-901.

Szczesniak, A. S., M. A. Brandt, and H. H. Friedman. 1963 Development of standard rating scales for mechanical parameters of texture and correlation between the objective and the sensory methods of texture evaluation. J. Food Sci. 28:397-403.
Terzaghi, B. E., and W. E. Sandine. 1975. Improved medium for lactic streptococci and their bacteriophages. Appl. Environ. Microbiol. 29:807-813.

Urbach, G. 1997. The flavor of milk and dairy products: II. Cheese: Contribution of volatile compounds. Int. J. Dairy Technol. 50:7989.

Van Vliet, T. 1991. Rheological and fracture properties of cheese: Terminology to be used in cheese rheology. Bulletin of the IDF 268:5-15. 